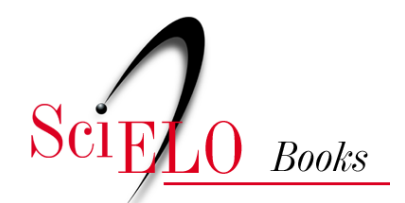

\title{
Capítulo 5 - 0 harém ao rés do chão fronteiras e personagens
}

\author{
Marina de Oliveira Soares
}

\section{SciELO Books / SciELO Livros / SciELO Libros}

SOARES, M. $\mathrm{O} . \mathrm{O}$ harém ao rés do chão: fronteiras e personagens. In: $O$ harém ao rés do chão: imaginário europeu e representações médicas sobre o lugar-segredo, 1599-1791 [online]. São Bernardo do Campo, SP: Editora UFABC, 2017, pp. 397-474. ISBN 978-85-68576-81-6. https://doi.org/10.7476/9788568576816.0007.

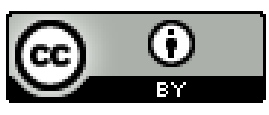

All the contents of this work, except where otherwise noted, is licensed under a Creative Commons Attribution 4.0 $\underline{\text { International license. }}$

Todo o conteúdo deste trabalho, exceto quando houver ressalva, é publicado sob a licença Creative Commons Atribição $\underline{4.0}$.

Todo el contenido de esta obra, excepto donde se indique lo contrario, está bajo licencia de la licencia $\underline{\text { Creative }}$ Commons Reconocimento 4.0. 


\section{O harém ao rés do chão: fronteíras e personagens}

Ao tratarem o tema do harém nas sociedades islâmicas, os autores apontam recorrentemente três elementos: (i) o harém como fronteira entre permitido [halāl] e proibido [harām], (ii) como sinônimo de espaço físico e (iii) como sinônimo de feminino ${ }^{99}$. Atrelado ao primeiro item, indica-se também o teor de sagrado que a palavra harém carrega. Diante disso, busca-se neste capítulo seguir os vestígios do termo harém, considerando-se os itens citados, assim como os indicadores conceituais já ressaltados pelos dezesseis viajantes estudados nos capítulos anteriores. O cenário das representações europeias sobre o harém será somado, então, à verificação histórica da palavra, o que nos permitirá responder sobre a construção imaginária do harém, problema-chave colocado no início deste livro.

99 Dentre os autores que se dedicam a este tema, pode-se citar: Talhami, 2013, p. 158-159; Campo, 2009, p. 291-293; Chebel, 2003, p. 381-386 (Tomo I); Mernissi, 2002, p. 103-120. 


\subsection{0 harém como santuárío}

A primeira acepção relacionada à palavra harém da qual os outros significados derivam - é o seu caráter de proibição. O termo harém em português - cuja origem é o harim em árabe - está indicado no Alcorão e nas práticas do islamismo. Acredita-se, portanto, que as ações interditadas no islamismo foram criadas por Deus. O oposto de harām ${ }^{100}$, ilícito, é halāl, ou seja, aquilo que é permitido. As escolas de jurisprudência surgidas após a morte do profeta, em 632, flexibilizaram essas duas categorias, propondo que as ações fossem interpretadas a partir de cinco parâmetros: proibido, desencorajado, meramente permitido, recomendado e obrigatório (CAMPO, 2009, p. 284). Dentre as práticas proibidas, estão os "jogos de azar, a bebida alcoólica, a usura e os alimentos ilícitos", por exemplo, a carne de porco (MELTON; BAUMANN, 2010, p. 1517).

Dentro dessa acepção, está embutido um elemento já mencionado anteriormente: a face sagrada do harém. Ao definir esse termo em seu texto de viagem, o sueco Jean Otter chamava a atenção para o valor de "sagrado" denotado pela palavra. Esse significado também foi lembrado pelo viajante Jean Chardin. No capítulo intitulado "Do palácio das mulheres do rei", Chardin afirmava que a palavra harém [Haram] usada pelos persas indicava "lugar sagrado", sendo o espaço onde ficavam os apartamentos

100 A combinação das consoantes, que formam a raiz de uma palavra em árabe, com as vogais origina novas palavras, mas mantém o mesmo significado. Nesse caso, as palavras derivadas da raiz "h-r-m" guardam o sentido de proibido ou sagrado. Ver Cornell, vol. 4, 2007, p. 26. 
das mulheres. Os turcos, por sua vez, nomeavam tais apartamentos de serralho que significa "uma grande moradia" (CHARDIN, 1711, tomo 6, p. 217). A palavra - completava o viajante - vinha do hebraico e se encontrava em vários lugares dos livros de Moisés, denotando o sentido de "ilícito, proibido, interdito, aversão, excomunhão" (p. 217-218).

Jean Otter, como vimos no Capítulo 2, iniciava a sua definição de harém ressaltando a sacralidade em torno das cidades de Meca e de Medina. De fato, afora o caráter de proibição, o harém remete à ideia de sagrado. Nesse sentido, as cidades de Meca e de Medina, além da Esplanada das Mesquitas em Jerusalém, são considerados locais sagrados no islamismo (GLASSÉ, 2002, p. 170). Nas duas cidades sauditas, nomeadas de al-haramaīn ou "os dois locais sagrados", ocorrem cinco interdições: (i) apenas é possível entrar nas cidades sendo um peregrino ou com finalidade religiosa; (ii) a luta com os habitantes das cidades deve ser evitada tanto quanto for possível; (iii) a caça é proibida, exceto quando se tratar de "animais perigosos"; (iv) o corte de árvores é vedado, e, para exercerem o cultivo, os homens devem ter autorização; (v) "os não muçulmanos ou infiéis" não podem entrar ou se estabelecer nas cidades, além de não poderem ser aí sepultados. Essas determinações também valem para parte do Hijāz [barreira], região localizada a oeste da Árabia Saudita (LANE; REDISSI, 2009, p. 160).

De acordo com o historiador Andrew Rippin, a raiz da palavra harém [h-r-m] é usada oitenta e três vezes no Alcorão. Assim, encontramos referência à Caaba [Ka'abah] como "Casa sagrada" [al-bayt al-harām], 
além de alusão à "Mesquita sagrada" [al-masjid al-harām], nesse caso, em quinze ocasiões (RIPPIN apud LEAMAN, 2006, p. 249). Rippin lembra ainda que Deus designou determinados lugares como "marcos sagrados" [al-mash'ar al-harām], uma vez que estes estão relacionados à peregrinação. Há por fim outras suras que alertam sobre as "coisas sagradas" [hurumat] (p. 250). O que todas essas menções indicam é a conexão com o desígnio divino, ou seja, com aquilo que Deus ordenou para orientar a humanidade. Se em alguns momentos o harém guarda o sentido de imaculado, puro, em outros, pode indicar a fronteira do proibido.

Não era, contudo, esse significado de harém o mais ressaltado pelos viajantes. Todos aqueles que se puseram a descrever o harém - fosse a partir de sua própria experiência ou baseando-se em outras fontes - conceituaram o harém como um espaço; em particular, um espaço dentro do palácio real. Até hoje, quem se debruça sobre o tema acentua a origem sagrada que a palavra harém evoca, assinalando em seguida que o harém remete à parte do palácio ou da residência das classes abastadas onde ficavam as mulheres ${ }^{101}$. São as origens das fronteiras desse espaço físico que serão discutidas no item a seguir.

\subsection{O harém como espaço}

Embora os autores de viagem discordassem em determinados pontos quanto ao conceito de harém, nenhum

101 Ver "Harem" (TALHAMI, 2013, p. 158). 
deles deixou de mencionar a característica que lhes parecia indiscutível: o harém era um espaço físico. A maior parte deles, como vimos, estava interessada em descrever o harém do palácio imperial, mas houve também quem narrasse os acontecimentos envolvendo o harém das casas comuns, como fizeram Jean de La Roque e Jean Otter. Diante disso, é preciso examinar as origens e o desenvolvimento do harém como espaço físico nas sociedades islâmicas, a fim de comparar com as observações tecidas pelos autores europeus na modernidade.

A separação do espaço feminino em relação ao masculino não remete às sociedades islâmicas. A habitação exclusiva das mulheres dentro da casa era encontrada como prática corrente em sociedades antigas da Mesopotâmia, da Grécia e da Pérsia. Desse modo, a palavra harém em árabe [harim] encontra paralelo no haremlik turco, no andarun persa, no zenana ou andarpar urdu/ híndi (SMITH, 2008, p. 536). A divisão física entre homens e mulheres pode ser apontada ainda em outras sociedades da Ásia - como China e Japão - e na África (WALTHALL, 2008). Em relação ao tema que nos interessa particularmente aqui, é preciso buscar a fonte de tal divisão nos momentos iniciais da vida do profeta Muḥammad e no livro sagrado do Islã.

A história dos eventos privados da vida de Muhammad se tornava, por suposto, modelo de conduta para os muçulmanos. No caso específico da separação do espaço físico, um episódio protagonizado por ele seria incorporado não apenas às normas da relação entre o profeta e os crentes, como faria parte do próprio livro sagrado do islamismo. O episódio em questão se refere ao 
casamento de Muhammad com Zaynab, sua sétima esposa e casada com o filho adotivo do profeta, Zayd (SCHROEDER, 2002, p. 106). A união, que ocorreu após o divórcio de Zayd e Zaynab, foi relatada em texto pelo historiador persa Muḥammad Ibn Jarir al-Tabari (839-923).

Após o banquete de casamento, os convidados haviam se retirado, à exceção de três, que seguiam conversando. Contrariado, Muhammad saiu em direção ao aposento de 'Á'iša e de suas outras esposas. Ao voltar para o aposento de Zaynab, ele notou que os convidados ainda não haviam partido. Muhammad sairia outra vez em direção ao quarto de ' $\bar{A}$ 'iša e, quando retornou, posicionou um pé na alcova e manteve o outro do lado de fora. Foi neste momento que uma cortina [sitr] foi colocada entre o profeta e o convidado Anas Ibn Mālik, sendo o "versículo do véu" [hijāb] recitado (MERNISSI, 2002, p. 105).

A pronunciação do profeta a partir da interposição da cortina entre ele e o seu convidado foi convertida no verso 53 da sura 33, a "sura dos partidos". Nela, lê-se:

Ó, vós que credes! Não entreis nas casas do profeta - a menos que vo-lo seja permitido - para uma refeição, sem esperardes por seu tempo de preparo; mas, se sois convocado, entrai; então, quando vos houverdes alimentado, espalhai-vos, e não vos recreando em conversações. Por certo, isso molestava o Profeta, e, ele se peja de ter de fazer-vos sair. E Allah não Se peja da verdade. $\mathrm{E}$, se lhes perguntais por algo, perguntai-lhes, por trás de um véu. Isso é mais puro para vossos corações e os corações delas (NASR, 2005, p. 690-691, grifo meu).

Como se pode verificar, essa sura, que nasceu de um problema prático da vida do profeta, não instituía em 
princípio a separação do espaço físico entre um homem e uma mulher, mas entre os recém-casados e os homens. Além disso, como nos lembra Fatima Mernissi, Muhammad era conhecido por seu caráter meditativo, o que se traduzia em profunda reflexão antes da tomada de qualquer decisão. No caso do "versículo do véu", não é apenas digna de nota a rapidez com que a sentença foi postulada, como também o profundo impacto que um evento sem importância teria na vida da comunidade, isto é, a divisão do “espaço muçulmano em dois" (MERNISSI, 2002, p. 107).

A segunda parte do versículo, contudo, transcendia o evento que lhe havia originado e passava a marcar a separação entre os crentes e as mulheres do profeta. Como lembrou Irvin Schick, o "versículo do véu" é "incidentalmente a origem da palavra purdah - que significa literalmente cortina ou véu em persa - e que denota reclusão feminina na Índia” (SCHICK apud BOOTH, 2010, p. 70). $\mathrm{Na}$ mesma sura, há uma mensagem dirigida às mulheres do profeta, orientando sobre a diferença entre o espaço privado e o espaço público. Nesse versículo é indicado: "E permanecei em vossas casas, e não façais exibição de vossos encantos corporais como a exibição dos idos Tempos da Ignorância”, ou seja, no período anterior ao advento do islamismo [Jahilīyyah] (NASR, 2005, p. 685).

Nesse momento inicial da sociedade islâmica, o gineceu do profeta possuía uma característica distinta em relação ao espaço privado feminino nos séculos posteriores: a reclusão das mulheres era parcial, o que significa que elas participavam da vida em sociedade. Como escreveu Juan Eduardo Campo, nos ahädìth e nas primeiras narrativas históricas desse período, há indicações de que as 
"mulheres poderiam desempenhar funções de importância central no início da comunidade islâmica, tais como as esposas de Muḥammad: Hadīja (m. 619) e 'Ā'iša (m. 678)" (CAMPOS, 2009, p. 292). Hुadīja não era apenas uma comerciante bem-sucedida como também a maior apoiadora de Muḥammad quando das primeiras revelações de Deus ao seu marido. Já ' $\overline{\mathrm{A}}$ 'iša era conhecida por expressar os seus pensamentos e a sua liderança. Diante disso, o profeta relatava que se aconselhava com elas em "assuntos políticos e sociais" (AFKHAMI; FRIEDL, 1997, p. 88).

A forma como Muhammad tratava o ambiente da casa também é elucidativa da comunicação que ele buscava manter entre o espaço privado e o público. Quando chegou a Medina, em 622, Muhammad e as suas esposas ficaram alojados na casa de uma família da cidade. Certo tempo depois, ele pagaria pelo terreno de um medinense, chamado Abu Ayyu, para construir ali a sua habitação e uma mesquita. Ao final da obra, além da mesquita, havia nove quartos. Aqueles ocupados pelas mulheres eram nomeados de buyut [plural de bayt, casa] ou hujurāt, que significa aposento. Como o quarto de ' $\overline{\mathrm{A}}$ 'iša possuía “acesso direto à mesquita", o profeta passava por este aposento quando ia rezar (MERNISSI, 2002, p. 126). Embora houvesse tal construção, há ahädìth que "sugerem que esta prática não durou” (SCHICK apud BOOTH, 2010, p. 70).

À medida que as relações de poliginia se disseminavam pela sociedade islâmica, uma soma crescente de mulheres era incorporada ao gineceu dos homens muçulmanos. Sobre isso, basta lembrar o número de mulheres do profeta: onze esposas e "talvez duas concubinas"102.

102 Sobre as mulheres de Muhammad, ver Peters, 2003, p. 84. 
O quarto califa e genro de Muḥammad, cAlī Ibn Abi Talib, após o casamento com Fātima (m. 633), teria se casado com outras nove mulheres. Já sobre Hassan (625669/670), um dos filhos de 'Alī e de Fātima, é relatado que ele se casara com até cem mulheres (CAMPO, 2009, p. 292). Uma sura revelada após a "Batalha de Udud", em 625, travada entre o grupo de Medina, liderado pelo profeta, e o de Meca, instaurava um limite no conjunto de esposas a que um muçulmano poderia se unir. $\mathrm{Na}$ "sura das mulheres", estabelecia-se que o crente poderia se casar com "duas, três ou quatro" mulheres. Mas se temesse não ser justo, deveria se contentar com as escravas que possuísse (NASR, 2005, p. 124).

Durante esse período e pelo menos até o califado abássida $(750-1258)^{103}$, o termo harém raramente era empregado. No caso do califado abássida em particular, as fontes consultadas pelo historiador Hugh Kennedy apontavam o huram do califa, palavra que, embora tenha a mesma origem que a palavra harém, referia-se às mulheres e a todas as outras pessoas que estavam sob o controle do soberano (BOOTH, 2010, p. 90). Nesse sentido, não havia a rigor um espaço da casa ou do palácio destinado às mulheres, tratava-se antes de um grupo de pessoas vivendo sob o poder de tal governante. À época do califa Al-Muqtadir (895-932), havia autores que empregavam o termo $d u r$ - plural de dar [casa] - para se referirem às áreas privadas do palácio. Em outras fontes deste período - como nas "Anedotas" de Al-Tanūhī (940-994), de Basra

103 Sobre o califado que sucedeu os omíadas (661-750), ver Benisson, 2009. 
[Iraque] -, as indicações sobre as áreas privadas dos palácios eram nomeadas de dur al-huram.

Foi durante a dinastia abássida que a residência do califa sofreria mudanças a ponto de se transformar em um complexo constituído por outros palácios. O exemplo citado por Marilyn Booth aponta que o espaço privado dentro da residência do califa não apenas sinalizava fronteiras físicas como também passava a indicar um espaço destinado às mulheres. Booth menciona o reinado de Al-Muqtadir, no século X, afirmando que a "casa do califa" ou, como era conhecido, "Dar al-Khilafa", era simultaneamente um local de "representação do poder do califa, assim como o centro administrativo de um vasto império e uma residência para a família do califa" (BOOTH, 2010, p. 91). No grupo de mulheres, além da mãe do califa, de suas irmãs e tias, estavam também as suas esposas, concubinas e crianças. Como afirma Booth, os quartos separados das mulheres devem ter emergido nesta época.

Num cenário em que as fronteiras entre homens e mulheres não estavam fixamente determinadas, é preciso uma vez mais salientar a etimologia da palavra harém. Como já foi notado, a raiz $h-r-m$ é associada na língua árabe, "e em outras línguas semíticas como o hebraico", a "noções de tabu, inviolabilidade e caráter sacrossanto" (VAN GELDER, 2005, p. 5). Confirma-se, a partir daí, que o termo não possuía originalmente uma conotação de gênero, como lembrou Booth. Portanto, nem a palavra guardava um sentido de reclusão feminina - no tocante ao espaço físico - nem foi utilizada desde o início do Islã com esse intento. O que Irvin Schick defende, contudo, é que a segregação sexual cresceu após a morte do profeta. 
As razões para isso estavam tanto nas posturas rigorosas do califa ${ }^{\mathrm{C} U m a r}$ al-Hațāb (governou ${ }^{104}$ entre 634 e 644) quanto na influência recebida dos povos com os quais os árabes travavam contato (SCHICK apud BOOTH, 2010, p. 71).

Sobre a expressão "segregação sexual" usada por Schick, o autor faz uma ressalva. Homens e mulheres adultos muçulmanos podem partilhar o mesmo espaço, desde que estejam impossibilitados de se casarem um com o outro em razão do parentesco. Este está baseado na "consanguinidade, na partilha de uma mesma amamentadora, no casamento ou na união sexual, como explicitamente estipulado no Alcorão" (SCHICK apud BOOTH, 2010, p. 71). A partir disso, conclui-se que é vedado ao homem entrar em um ambiente onde esteja uma mulher que não seja a sua parenta. O fato é: como os homens e as mulheres, em sua maior parte, não são parentes uns dos outros, a consequência foi que o "versículo do véu" foi interpretado como um marcador de dois subespaços, um masculino e outro feminino (p. 71).

\subsection{0 harém como espaço femíníno}

A demarcação do espaço feminino dentro dos palácios islâmicos - e em casas comuns de famílias abastadas - torna-se produto do califado abássida ${ }^{105}$. Dentre os

104 Nas próximas indicações, usarei apenas “g." como sinônimo de "governou”. 105 Sobre a sociedade islâmica entre os séculos X e XIII, Aly Mazahéri afirma que o harém se resumia em um "luxo apenas acessível à classe abastada da sociedade; com efeito, não podia pôr-se a questão, para as pessoas de condição modesta, de possuírem um harém" ([s. d.], p. 70). 
governantes desta dinastia - e de seu conjunto de esposas e concubinas -, nenhum ficaria mais conhecido pelos séculos posteriores do que Hāārūn Ar-Rašīd (c. 766-809). O quinto califa abássida, que governou entre 786 e 809, é definido por Fatima Mernissi como um personagem inspirador, dada a sua beleza, a sua inteligência, o seu interesse pela ciência e os seus sucessos militares. Além de tais atribuições, Ḥārūn Ar-Rašīd é o califa descrito em contos do "Livro das Mil e Uma Noites", obra que para Tayeb El-Hibri foi responsável por melhor promover o nome do governante no Ocidente (EL-HIBRI, 1999, p. 17). O seu harém - que passara a evocar tanto o sentido espacial como também se relacionava às mulheres que o habitavam - teria abrigado, entre esposas, concubinas e escravas [jawārī] , duas mil mulheres (LOCKARD, 2008, p. 281).

Ḥārūn Ar-Rašīd viveu no palácio construído à época de Al-Mansūr, califa que fundou a cidade de Bagdá em 762 e que a apelidou de Madīnat As-Salām [cidade da paz] (HUNT, 2005, p. 41). O "Palácio da porta dourada"106 possuía um "grande domo verde" e era tão suntuoso que, se comparado "à propriedade incompleta de Carlos Magno", deixaria evidente a extrema modéstia desta última (BOBRICK, 2012, p. 141). No palácio, viviam a família do califa, os seus funcionários e servos. Além de residência, tratava-se de um espaço destinado a abrigar o arsenal de armas, a tesouraria e os gabinetes do governo (BLOOM; BLAIR, 2009, p. 250). Contudo, como escreveu Guy Le Strange, orientalista inglês (1854-1933), o "Palácio da

106 Sobre esse palácio, ver "New additions to the new edition" (ALLAN apud GRABAR, 1991, p. 12-22). 
porta dourada" entrou em completa ruína ainda no século X (2011, p. 318 $)^{107}$. Nesse sentido, se as informações a respeito dos palácios otomanos são numerosas na historiografia contemporânea ${ }^{108}$, o mesmo não se pode atestar sobre o palácio construído por Al-Mansūr. Aqui vale a questão: o que podemos afirmar sobre o harém de Ḥārūn Ar-Rašīd, se pouco conhecemos a estrutura e a organização interna do palácio oficial?

Se os dados sobre o palácio de Ḥārūn Ar-Rašīi e de que modo viviam as mulheres dentro de tal construção são escassos, as informações ou especulações sobre as esposas, concubinas e escravas do califa são abundantes. O estudioso egípcio Jalāl al-Dīn al-Suyūṭī (1445-1505), escrevendo sobre os califas islâmicos, ressaltava a notável inclinação de Ar-Rašīd em se apaixonar pelas mulheres (1881, p. 299). Diante disso, o califa - que se casou aos dezesseis anos com a sua prima Zubaydah - é descrito como um personagem de intensos desejos sexuais, cuja vida seria povoada de encontros amorosos (BOBRICK, 2012, p. 54). A aquisição de "numerosas escravas bem treinadas como concubinas" (RINGDAL, 2004, p. 134) e guardadas por eunucos resume-se em uma representação bem próxima daquela que lemos nos autores de viagem modernos.

É esse o cenário retratado em uma das poucas fontes textuais sobre o palácio de Al-Muqtadir, califa que reinou entre 908 e 932. O já citado 'Alī al-Tanūhī dedicou-se em

${ }_{107}$ A obra de Le Strange, Baghdad: During the Abbasid Caliphate, foi publicada em 1901.

${ }^{108}$ Um dos livros de relevo sobre esse tema é o de Norman Mosley Penzer (1952) citado no Capítulo 1. Em relação às pesquisas mais recentes, destacam-se: Mansel, 1995; Peirce, 1993; Necipoğlu, 1991. 
sua obra mais famosa, Kitāb Al-Faraj ba'da l-shidda [Livro do alívio após a adversidade], a descrever anedotas dispostas originalmente em quatorze capítulos. Para confirmar a veracidade de seu texto, Al-Tanūhī se utilizava de correntes de transmissores e usava afirmações como “"Eu ouvi... Foi-me dito... Eu li'” (EL CHEIKH apud MARÍN; DEGUILHEM, 2002, p. 131). Nesse livro, Nadia El Cheikh lembra que o autor mencionava os corredores e os portões do palácio, além da área em que ficava o harém este sendo guardado pelos eunucos. Para El Cheikh, o que merece destaque é a fronteira e a distância entre o harém e as partes públicas do palácio do califa ressaltadas por Al-Tanūh̄ī (EL CHEIKH, 2005, p. 7-8).

A partir do texto de Al-Tanūhī, verificam-se as duas acepções tomadas pela palavra harém: um espaço físico e um lugar habitado por mulheres. El Cheikh condensa esses dois significados ao afirmar que as qahramānas - mulheres encarregadas de funções administrativas dentro da residência do califa ${ }^{109}$ - tinham o "privilégio de entrar e sair do palácio" para desempenhar tarefas para as suas senhoras, uma vez que "as mulheres do harém, mesmo as concubinas", não tinham permissão para se retirar de tal residência (EL CHEIKH apud MARÍN; DEGUILHEM, 2002, p. 141). As qahramānas promoviam a comunicação entre "o harém e a corte, e entre o harém e o mundo externo" (EL CHEIKH, 2005, p. 10). Diante disso, El Cheikh reforça a necessidade de se encarar o harém abássida como uma "unidade social organizada" e não como

109 Sobre as qahramanas, ver The Qabramâna in the Abbasid Court: Position and Functions (EL CHEIKH, 2003). 
um "lugar ocioso" (apud MARÍN; DEGUILHEM, 2002, p. 142).

Um dos temas de maior curiosidade entre os europeus na modernidade se referia ao número de mulheres que habitavam os haréns. Este tópico também fez parte das narrativas daqueles que escreviam sobre o califado abássida. Sobre o harém de Al-Muqtadir, o burocrata e historiador bagdali Hilāl al-Ṣābi’ (969-1056) afirmava: "acredita-se que nos dias de al-Muqtadir [...] a residência continha 11.000 servos [...] 4.000 garotas livres e escravas, e milhares de servos de câmaras" (1964 apud EL CHEIKH, 2005, p. 8). Al-Șābi' apontaria ainda que em 918 Umm Al-Muqtadir [Mãe de Al-Muqtadir] receberia um subsídio mensal para manter os "príncipes, os parentes femininos e os servos” no palácio.

Num cenário de múltiplas mulheres, com idades e origens diversas, a complexidade de organização do harém se tornava notória. Assim, as concubinas - que possuíam tal condição justamente por não serem esposas legais do califa - passavam a usufruir do status de Umm al-walad, [literalmente, mãe de um menino] quando tinham um filho com um homem livre. Isso significa que a partir desse momento, a concubina, que era uma escrava ${ }^{110}$, não poderia ser vendida, entregue como presente ou deixada como herança. Ela permanecia sob o domínio de seu senhor e conquistaria a liberdade quando da morte deste.

\footnotetext{
110 Sob a lei islâmica, uma escrava era definida como uma "mulher que havia sido tomada como despojo de guerra, ou nascido de pais escravos, ou comprada" (CASWELL, 2011, p. 12). Já a concubina era uma escrava que mantinha relacionamento sexual com o seu senhor. Sobre isso, ver Meri, 2006, p. 169-170.
} 
Como explica Fuad Caswell, durante o período abássida as escravas podiam ser divididas em dois grandes grupos: (i) as domésticas e (ii) as trabalhadoras. As domésticas, por sua vez, subdividiam-se em outros dois grupos: aquelas que desempenhavam funções na cozinha ou executavam outras tarefas dessa natureza, sendo normalmente de origem indiana ou africana negra; e aquelas que tinham um "valor de 'entretenimento" (CASWELL, 2011, p. 14). Aqui, as habilidades desejadas compreendiam não apenas o conhecimento em música e em artes, por exemplo, mas também os seus atributos sexuais. Desse modo, havia escravas cujos dotes eram exibidos publicamente, e outras que se tornavam propriedade de um único senhor. É neste grupo que se encontravam as concubinas.

O harém, enquanto um espaço destinado à convivência de várias esposas e concubinas, não era por suposto uma realidade para a maior parte dos homens muçulmanos durante o califado abássida. Embora Amira Bennison defenda que a "mistura cultural" que ocorria nos haréns dos califas também refletia na sociedade do período (2009, p. 117), os escassos dados sobre as "pessoas comuns" não permitem que apontemos a presença do harém em suas casas. A influência da vida palaciana na vida ordinária, sustentada por Bennison, consistia na prática de se tomarem mulheres estrangeiras como esposas ou concubinas, ainda que a monogamia fosse a "situação mais comum" (p. 117).

Dentre os governantes islâmicos, houve também aqueles que defenderam o casamento monogâmico. Alguns califas fatímidas - representantes da dinastia xiita ${ }^{111}$

111 Para uma discussão sobre o xiismo, cujo termo remete a Shī'atu ' ${ }^{\mathrm{c}} \mathrm{Al}$, ou partidários de ${ }^{\mathrm{c}} \mathrm{Al}$, , ver Bennett, 2013, p. 135-162. 
ismaelita que governou o Norte da África, especialmente o Egito, entre 909 e 1171 - inclinaram-se "em direção à monogamia", exortando, por conseguinte, "os seus súditos a adotarem esse tipo de organização familiar" (SONN, 1996, p. 127). O quarto califa fatímida, Al-Mu'izz (g. 953-975), teria discursado aos chefes das tribos do Norte da África pedindo-lhes que se casassem com uma só mulher, pois isso aumentaria a sua felicidade e preservaria a "força da alma" (p. 127). A defesa do casamento monogâmico nesta dinastia tanto fazia alusão a ${ }^{c} A l \bar{i}$, que ficara casado com Fātima até à morte desta, quanto ressaltava a "imagem de probidade do imām-califa fatímida, em contraste com a licenciosidade percebida de outras dinastias rivais" (CORTESE; CALDERINI, 2006, p. 52).

Percebe-se a partir desse discurso a acentuação de um elemento que se tornaria mais evidente nas representações sobre as sociedades otomanas: a sexualidade presente no harém. É certo que a exacerbação do comportamento sexual dos islâmicos já era matéria de debate entre os europeus desde o período medieval. Contudo, neste momento, as justificativas sobre tal vício eram remetidas recorrentemente ao profeta Muhammad. Lembremos que os textos dos cristãos medievais não apenas apontavam Muhammad como um falso profeta, mas enfatizavam que ele dissimulava a sua "missão espiritual" em busca de "satisfazer a sua luxúria e a sua ambição” (TOLAN, 2002, p. 148). Já no período moderno, a intensa sexualidade dos muçulmanos - assim percebida pelos europeus - se transformava em um cenário difuso do qual o harém fazia parte. 


\subsection{O harém e os seus personagens}

Através das narrativas dos viajantes europeus, analisadas nos Capítulos 1 e 2, pudemos perceber as distintas posturas em relação ao tema do harém. Em primeiro lugar, é preciso relembrar que nem todos os autores usavam essa palavra para indicar o espaço destinado ao convívio feminino nos palácios islâmicos. O termo serralho era, como já assinalado, prevalente em relação à palavra harém. Isso não impediu que se formasse a crença generalizada de que o harém otomano era povoado por mulheres detentoras de um poder nefasto sobre a política do império. Ao lado disso, é digna de nota a extensa população masculina presente nos palácios imperiais e a insistência dos europeus em ressaltar as relações entre os jovens rapazes e os governantes otomanos. Os eunucos eram, por fim, figuras correntes nas descrições sobre o harém. Vejamos cada um desses três itens.

\subsubsection{Serralho e harém}

Embora já tenha notado anteriormente, é importante recuperar a íntima ligação conceitual entre as palavras serralho e harém feita pelos viajantes-autores do período moderno. Antes disso, é preciso lembrar que a maior parte dos autores do século XVII citados no Capítulo 1 não utilizava a palavra harém nas suas narrativas de viagem. A única exceção foi o joalheiro francês Jean Chardin. No século XVIII, observa-se justamente o oposto, ou seja, apenas um autor, Joseph Pitton de Tournefort, não empregou o termo harém em sua narrativa. Em resumo, 
nesses textos o serralho era entendido ou como sinônimo de palácio ou como a parte do palácio onde o soberano descansava junto às mulheres e crianças, isto é, um lugar de acesso restrito. A ausência da palavra harém ou a indistinção em relação ao serralho não impediram por suposto que os viajantes descrevessem a vida privada dos turcos e o convívio com as mulheres dentro do palácio. Diante disso, cabe examinar de que forma se organizava o palácio imperial otomano e como operavam as relações entre os sultões e as mulheres que aí viviam.

$* * *$

Após a conquista da capital do Império Bizantino pelos otomanos em 1453, a cidade recebeu um grande esforço de revitalização por parte de Mehmet II (1432-1481), sultão conhecido como "o conquistador" [al-Fātih]. Dentre as suas ações, figurava a construção do palácio que ficaria conhecido como Eski Saray, ou "Velho Serralho", em contraposição ao "Novo Serralho", isto é, o palácio de Topkapı. Foi Mehmet, portanto, quem introduziu a "ideia de uma residência permanente para o sultão" (KIA, 2011, p. 37). O "Velho Serralho" foi construído na "Terceira Colina", sendo esta descrita pelo historiador grego Kritovoulos [ou Kritoboulos] (c. 1410-c. 1470), como "a melhor localização no centro da cidade" (1954 apud FREELY, 2011, p. 103). A construção desse palácio ocorreu entre 1457 e 1458. A partir do governo de Sulaymān, o Magnífico, em 1520, "os sultões abandonaram o Velho Palácio em favor do Novo Palácio na primeira colina" (FREELY, 2011, p. 120). A construção do palácio Topkapi se iniciou em 1465 e foi concluída em 1478. 
O palácio Topkapi havia sido originalmente designado como o centro administrativo do império, cabendo ao Eski Serralho abrigar a Corte e o harém. Tal prática foi seguida pelos três sucessores imediatos de Mehmet II: Bajazet II (g. 1481-1512), Selim I (g. 1512-1520) e Sulaymān, o Magnífico, cujo governo se estendeu de 1520 a 1566. No caso deste último, a sua esposa Roxana - citada no Capítulo 3 - teria conseguido a permissão do sultão para instalar-se no Topkapi, "mas provavelmente apenas nos pavilhões de madeira" (FREELY, 2011, p. 141). Alega-se que o mesmo ocorrera com o filho e sucessor de Sulaymān, Selim II (g. 1566-1574). As primeiras “estruturas permanentes no harém" teriam sido construídas pelo filho de Selim II e seu sucessor, Murat III (g. 1574-1595).

No século XVIII, o Topkapi era usado como "residência real de inverno" (ZARINEBAF, 2010, p. 23). Isso não impediu, contudo, que o sultão Ahmed III (g. 17031730) fizesse intervenções no palácio, adicionando uma fonte do lado externo do portão, assim como biblioteca, além de restaurar o saláo imperial, a sala de jantar e a câmara de petição. A decoração em padrão floral persa e no estilo rococó francês comporia as reformas feitas não apenas por Ahmed III como também por Abdulhamid I (g. 1774-1789) e Selim III (g. 1789-1807). Algumas construções do palácio Topkapi também foram danificadas ao longo do tempo, e dois pavilhões foram demolidos. Houve dois incêndios graves - em 1574 e em 1665 - que "devastaram grandes seções do palácio”. Nesse sentido, enquanto as três Cortes principais ainda preservam as suas disposições originais, feitas à época de Mehmet II, muitos outros edifícios desapareceram, sendo reconstruídos ou redecorados 
posteriormente. O harém estava localizado no quarto pátio do palácio, com vista para o Mar de Mármara.

Nas duas figuras seguintes, é possível verificar a área ocupada pelo harém dentro do palácio Topkapi (mapa 1) e a sua localização geográfica em Istambul (mapa 2). Nesse caso, a imagem indica a posição privilegiada do Topkapi, a qual oferecia tanto "poder de defesa quanto vista deslumbrante" (KIA, 2011, p. 37), uma vez que a construção está voltada para o Estreito de Bósforo, ao norte, e para o Mar de Mármara, a leste. No mapa, é possível ver ainda onde se construiu o Eski Serralho ou o "Velho Serralho" (indicado na área VI).

O palácio Topkapi estava dividido em quatro Cortes: uma área estava dedicada ao serviço e à segurança e era nomeada de "Birun, ou seção exterior"; um "centro administrativo" onde o Conselho Imperial se reunia; um espaço destinado à educação, "conhecido como Enderun, ou seção interior"; e, finalmente, uma área privada na qual se encontrava o "Harém ou seção das mulheres" (KIA, 2011, p. 37). O palácio estava cercado por sete portas, e uma delas estava protegida por várias peças de canhão, o que teria originado o nome Topkapı - que, em turco, significa "Porta de canhão" (PENZER, 1952, p. 17). O palácio propriamente dito possuía três portões: o "Portão Imperial" [Bab-i Hümayun]; o portão médio, chamado de "Portão da Saudação" [Bab-üs Selam]; e o terceiro portão, conhecido como "Portão da Felicidade" [Bab-üs Saadet]. Mehrdad Kia afirma que no auge do poder otomano o palácio Topkapi abrigou quatro mil residentes (KIA, 2011, p. 37). 


\section{Harém}

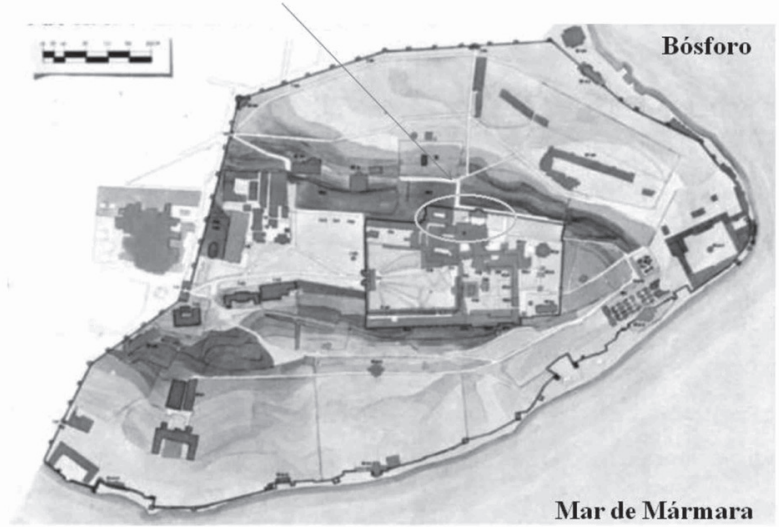

Mapa 1. Fonte: Adaptado de Öz (1983).

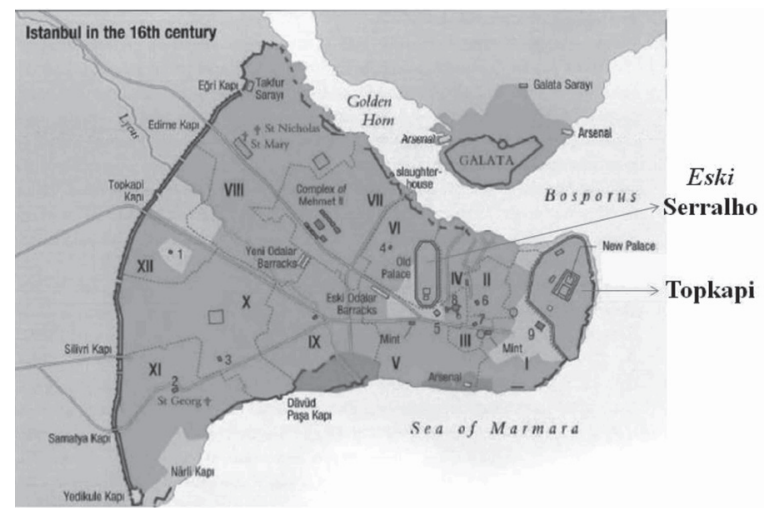

Mapa 2. Fonte: Nicolle (2008).

O palácio Topkapi, que foi construído sobre um antigo campo de oliveiras, abrange uma área de 700 mil metros quadrados. Diante disso, o número de quartos no harém era também abundante. Para Fariba Zarinebaf, havia “mais de trezentos quartos" (2010, p. 23). Já Kia acredita que o harém possuía "aproximadamente quatrocentos 
quartos" destinados à "mãe, às esposas, aos filhos do sultão, aos seus servos e atendentes" (2011, p. 39). Os quartos do harém, em seu estado atual, remetem em grande medida à época de "Murat III (g. 1574-1595), com reconstruções bastante extensas e adições principalmente sob Mehmet IV (g. 1648-1687) e Osman III (g. 1754-1757)" (FREELY, 2009, p. 98).

O escritor contemporâneo Charles FitzRoy, ao descrever Istambul no século XVIII a partir de uma série de viajantes, dedicou um capítulo inteiro ao palácio Topkapi. A divisão em três Cortes, além do harém, é recuperada pelo autor. A primeira Corte, conhecida como "Corte dos Janízaros", é descrita como "uma enorme área de terra batida aberta a todos", onde "cinquenta guardas na porta de entrada, fortemente armados com uma variedade de cimitarras e arcabuzes, não fazem nada para fazer você se sentir bem-vindo" (FITZROY, 2013, p. 97). Uma das características dessa Corte era o intenso silêncio, de modo que os visitantes que ali estavam não se arriscavam sequer a tossir. Apenas as saudações da banda imperial poderiam "quebrar o silêncio" pela manhã e ao anoitecer, ou quando se encerrasse uma "audiência de um embaixador com o sultão" (p. 98).

Esta primeira Corte abrigaria ainda a despensa com itens que iam da marmelada ao veneno, passando pela "urina do eunuco", considerada afrodisíaca; a padaria; a ourivesaria - com o propósito de produzir joias para as mulheres que habitavam o harém - e o hospital. John Freely notifica que, nesta Corte, encontravam-se também um arsenal, um espaço dedicado à produção de moedas e a tesouraria externa, além de "dormitórios para os guardas 
e empregados domésticos do Serviço Exterior”. Neste último caso, tratava-se de funcionários que normalmente não mantinham contato com o sultão e com a sua família (FREELY, 2009, p. 99).

A segunda Corte, ou Corte do Diwān ${ }^{112}$, era assim conhecida por abrigar o local "devotado à administração pública do império” (FREELY, 2009, p. 99). Diante disso, eram admitidos nesta Corte todos aqueles que possuíam assuntos burocráticos para discutir com o sultão e com o seu conselho. Ficavam neste espaço as cozinhas e os estábulos privados. Esta Corte exibia uma aparente tranquilidade, como escreveu FitzRoy. Contudo, ali estavam construídas as celas para prender aqueles que houvessem ofendido o sultão. Na mais notável destas celas, estavam os irmãos mais jovens do sultão, guardados por surdos-mudos e por "mulheres que haviam sido esterilizadas à força” (FITZROY, 2013, p. 99). Para justificar a primeira parte de sua afirmação, FitzRoy cita como fonte o viajante francês Jean-Claude Flachat (1700-1775) que esteve em Istambul em 1740. O chefe dos eunucos negros é quem havia descrito a prisão dos príncipes para o viajante francês, assegurando-lhe da "natureza claustrofóbica" em que eles viviam.

A terceira Corte estava destinada aos funcionários do governo e abrangia as várias divisões da Escola do Palácio. Além da escola, ali se encontravam algumas câmaras do Selamlık, ou "salas de recepção do sultão", e os alojamentos dos eunucos brancos, uma vez que eles cuidavam

112 A palavra diwān [دي وان , em árabe] significa tanto um local de reuniões políticas ou burocráticas quanto uma coleção de escritos poéticos. Sobre isso, ver Lewis; Churchill, 2009, p. 189. 
dos pajens e dos alunos da Escola do Palácio (FREELY, 2009, p. 98-99). FitzRoy afirma que as casas da Escola do Palácio abrigavam entre trezentos e quatrocentos jovens destinados a servir o seu senhor. Esses jovens eram educados com conhecimento de esporte, etiqueta do palácio, literatura e Alcorão, além de aprenderem fluentemente a língua turca, persa e árabe. Depois do treinamento, as funções reservadas a eles englobavam desde limpeza da câmara real até a posições de destaque no governo, como a de ministros e vizires do sultão.

A última grande seção do palácio era o harém. Para se ter acesso a ele, era necessário passar pelo "Portão da Felicidade" - como afirmado por Mehrdad Kia - ou "Porta dos eunucos brancos" (FITZROY, 2013, p. 102). No harém, não se localizavam apenas os quartos das mulheres, mas também outras salas do Selamlık, “o próprio quarto do sultão, e os quartos dos eunucos negros que guardavam os quartos das mulheres" (FREELY, 2009, p. 99). No item dedicado ao harém, FitzRoy exalta o fascínio que esse local despertava nos viajantes em virtude do luxo e do exotismo de tal lugar. Contudo, como pudemos ler nos Capítulos 1 e 2, os viajantes dos séculos XVII e XVIII nem sempre se dedicavam ao tema do harém e nenhum deles utilizava o termo "exótico" para se referir a esse espaço. Passemos, então, à discussão sobre como viviam as mulheres no harém do palácio Topkapi.

\subsubsection{As mulheres no harém}

Se a instituição do harém está relacionada à centralização do Império Otomano, no século XV, data também 
desta época o afluxo de escravos e escravas obtidos em vitórias militares na região dos Bálcãs. De acordo com Zarinebaf, "boa parte da população de Istambul era de origem servil durante o início do período moderno" (apud DEWALD, 2004, vol. 3, p. 134). Diante disso, é certo que o palácio otomano refletiria essa característica populacional. Enquanto muitos garotos escravos eram treinados e incorporados pelo sistema militar, as escravas eram direcionadas aos serviços domésticos, e "as mais jovens e bonitas” ingressavam no palácio real (p. 134).

As concubinas, que eram prisioneiras, "compradas ou oferecidas para o sultão como presentes", desempenhavam uma importante função dentro do Império Otomano (DUIKER; SPIELVOGEL, 2007, p. 426). Como defende Caroline Finkel, à medida que o império se tornava "mais islâmico", os "otomanos adotaram a prática de outras dinastias muçulmanas ao permitirem que as concubinas escravas, mais do que as suas esposas legais, gerassem os descendentes dos sultões" (FINKEL, 2005, p. xxxiii). O sistema de reprodução dentro do palácio tinha uma regra específica desde pelo menos o reinado de Mehmet II, qual seja, a de que as concubinas poderiam conceber apenas um único descendente masculino. Caso dessem à luz uma menina, elas poderiam ainda tentar engravidar de um menino. Assim que um bebê masculino tivesse nascido, a concubina não deveria ter uma próxima gravidez. A política de "uma mãe/um filho" tornava determinante a função das mães-concubinas em promover a ascensão de seu filho quando da morte de um sultão.

Para tornar efetiva tal política, medidas de restrição sexual eram empregadas. Após o nascimento de um 
filho, sabe-se que as mães concubinas eram afastadas do sultão. Ou seja, elas não mais possuíam elegibilidade para frequentar os aposentos do governante. Não está claro se essas concubinas eram retiradas do harém. De todo modo, a abstinência dessas mulheres vinha se somar à intensa rotatividade de parceiras sexuais desfrutada pelo sultão. No século XVI, o veneziano Luigi Bassani, que tinha conhecimento do funcionamento do palácio otomano, afirmava que o sultão escolhia as concubinas dentre as escravas que lhe eram apresentadas. Aquela que o agradava era colocada no serralho; mas, assim que ele se apaixonasse por outra, esta era repudiada, e o processo continuava tanto quanto ele quisesse (BASSANI, 1545, folha 21).

Para além dos desejos e das escolhas do sultão, a política sexual do harém respondia a outra necessidade da "Casa de Osman": aquela de garantir descendentes para o sultão reinante. Isso era essencial para evitar turbulências na sucessão dinástica, fosse pela ausência de filhos aptos a substituírem um governante assassinado, fosse no caso de disputas internas ocasionarem a morte do provável sucessor. Essas disputas de sucessão, e a própria necessidade de as mulheres se manterem no harém, geravam outra forma de controle de natalidade: a prática do aborto. $\mathrm{O}$ médico e naturalista escocês Patrick Russell (1726-1805), ao revisar e ampliar a narrativa de viagem para Alepo escrita por seu irmão - Alexander Russell (c. 1715-1768) -, indicava que o aborto era uma prática empregada pelas mulheres turcas (1794, vol. 2, p. xxxv). Ele afirmava ainda que "o número de crianças nos grandes haréns é pequeno em relação ao número de mulheres". Isso era tão notório, que os cristãos e os judeus acreditavam que "certos meios" eram usados 
tanto "para prevenir a concepção" quanto para levar ao aborto (RUSSELL, 1794, vol. 1, p. 298).

Antes de Russell, em 1719, o padre francês Marcel Ladoire, em viagem à Palestina, também fez menção ao assunto. Ladoire assumiu que acreditava, assim como outras pessoas, que os turcos - termo usado por ele para indicar os muçulmanos de forma ampla - tinham um grande número de filhos, mas que isso era um erro. Ele afirmava que os seus tradutores haviam lhe garantido que o número de crianças cristãs excedia o número de crianças muçulmanas. A razão dada para isso lhe parecia plausível: havia uma grande inveja entre as "mulheres turcas", de modo que quando uma delas ficava grávida, as outras empregavam todos os meios para fazê-la abortar. Por isso, era necessário que a mulher grávida tomasse precauções a fim de ter um parto exitoso (LADOIRE, 1720, p. 389).

$\mathrm{O}$ tema do aborto também foi registrado em relação aos persas. Ao escrever sobre o despovoamento da Pérsia, Jean Chardin listava três razões: a primeira era a "lamentável inclinação" desse povo às relações "contra a natureza", ou seja, homoeróticas; a segunda se referia à "luxúria imoderada do país"; e a terceira abarcava os problemas relacionados à manutenção de uma gravidez. Para Chardin, as mulheres se tornavam mães ainda cedo, mas não continuavam a ter filhos com o passar da idade. Os homens, embora tivessem várias mulheres, também não tinham muitos filhos. Somava-se a isso o fato de as mulheres fazerem uso de remédios para abortarem, especialmente nos três ou quatro primeiros meses de gestação, quando os seus maridos as abandonavam, pois tomavam por torpeza ou indecência se unirem a uma mulher grávida 
(CHARDIN, 1711, tomo 4, p. 12). Esse período coincidia com o argumento dos juristas islâmicos que defendiam o aborto. A prática era permitida nos 120 dias iniciais da gestação, afinal eles acreditavam que o feto ainda não possuía uma "alma humana" (TOLEDANO, 1998, p. 75).

No harém em particular, lembremos que Chardin alegava que ocorriam as "mais horríveis abominações do mundo", com "gravidez sufocada, abortos forçados" e a interrupção da vida de "criaturas recém-nascidas", ao negar-lhes "o leite, ou de alguma outra maneira" (1711, tomo 6 , p. 227). Remédios químicos, supositórios e poções "mágicas" de ervas estavam entre os métodos empregados para evitar a gravidez ou para induzir o aborto (ZILFI, 1997, p. 71). Diante das interferências na sexualidade e na procriação do harém, aquilo que deveria se traduzir em uma ampla fertilidade se transformava, de outro modo, em um "deserto de esterilidade" (AMES; LOVE, 2003, p. 62).

Dentro do palácio otomano, o status usufruído por uma concubina era equivalente àquele das escravas compradas pelos governantes abássidas, apontado anteriormente. Não era comum que um sultão se casasse com uma concubina, mas, caso desejasse oficializar tal união, o governante deveria primeiramente alforriá-la. Sob a lei islâmica, explica Leslie Peirce, o dono de uma escrava poderia desfrutar de acesso sexual legítimo junto a ela. Então, por definição, qualquer escrava era uma "potencial concubina”. A sua posição mudava social e legalmente quando ela engravidava de seu dono - fosse ele um sultão ou qualquer outro homem. Nesse momento, ela se tornava ümm i-veled - literalmente, "mãe de uma criança" -, e o seu filho 
passaria a lograr os mesmos direitos que o filho nascido de uma mãe livre (PEIRCE, 1993, p. 30-31).

As escravas tomadas pelos governantes otomanos foram divididas em dois grupos por John Freely. Na classe mais baixa, estavam as cariyeler, ou servas, que desempenhavam funções domésticas no palácio. Tais mulheres eram classificadas de acordo com a sua habilidade ou idade: as çırak eram aprendizes, as kalfa eram trabalhadoras qualificadas e as usta eram superintendentes. Essas escravas raramente entravam em contato com o sultão. Ainda assim, era possível que elas se aposentassem com "pensões confortáveis" (FREELY, 2011, p. 141). Na classe mais alta, estavam as gedikiler, ou privilegiadas. Essas mulheres eram compradas normalmente no mercado de escravos de Istambul, sendo "escolhidas por sua beleza e talento, e treinadas como musicistas, cantoras e dançarinas" (p. 141).

Após o processo de compra e o encaminhamento para o palácio, sabemos através de fontes de viagem que essas escravas eram convertidas ao islamismo - tópico citado com recorrência pelos viajantes lidos nos capítulos anteriores - e que eram destinadas a um amplo treinamento. Dentre as habilidades exploradas nesse processo, estavam por suposto o aprendizado do Alcorão, além do estudo de idiomas [o turco e o árabe deviam constar dessa lista], costura e bordado, conhecimentos musicais. Se as informações que dispomos sobre este tema soam superficiais e apressadas é porque as narrativas de viagem - maior fonte textual sobre esta matéria - tratam tal assunto de modo similar, repetido de maneira inequívoca em cada livro.

Não se está afirmando com isso que os viajantes prestavam informações deliberadamente erradas aos seus 
leitores. O que se percebe, de outro modo, é que os elementos característicos do palácio islâmico - abarcando-se o harém - formavam um bloco relativamente homogêneo e temporalmente congelado. Em outras palavras, a descrição do harém e das mulheres que o habitavam em um palácio norte-africano do século XVIII não raro era semelhante à descrição do harém do palácio otomano de dois séculos anteriores, sem prejuízo de entendimento. Voltarei a esta discussão no item sobre a imobilidade do harém.

Uma vez que a "tarefa central do harém" era a concepção de herdeiros masculinos a fim de garantir a continuação da dinastia otomana, o casamento legal dos sultões não vigorava como assunto de primeira ordem. Há autores que apontam a dependência exclusiva dos sultões em relação às concubinas, e a inexistência de esposas no harém (ÁGOSTON; MASTERS, 2009, p. 249). Esta afirmação, entretanto, não se sustenta. É fato que casamentos legais não ocorriam com ampla frequência entre os otomanos, contudo, eles aconteceram. Dentre esses matrimônios, o que maior escândalo causou na Corte Otomana foi o do sultão Sulaymān com Roxana [ou Roxalana], citada no Capítulo 3.

Roxana, que havia sido sequestrada pelos tártaros, fora entregue ao sultão Sulaymān por meio de seu vizir, Ibrahim. Depois disso, ela receberia o nome de Hürrem [alegre, em turco] e suplantaria o lugar da favorita do sultão, favorita esta que era mãe de Mustafa. O menino se tornou o único descendente vivo do sultão em 1521, ano em que dois outros filhos de Sulaymān morreram. O alto risco de mortalidade infantil e a necessidade de herdeiros impeliram o sultão a desconsiderar a regra que vigorava 
no palácio desde então, ou seja, aquela que restringia o nascimento de um menino para cada concubina. Como alega Leslie Peirce, "a habilidade de Hürrem em produzir filhos saudáveis" deve ter agradado ao sultão, a ponto de Hürrem dar à luz seis filhos de Sulaymān. Contudo, um deles, Abdullah, morreria três anos após o seu nascimento (PEIRCE, 1993, p. 60).

A violação maior da tradição viria em 1534 . Nesse ano, Sulaymān se casou com Hürrem, levando a "primeira concubina escrava na história otomana" a conquistar a liberdade e a alcançar a posição de esposa legal (PEIRCE, 1993, p. 61). Depois do casamento, Hürrem se mudou do "Velho Serralho" para o palácio Topkapi, alojando-se no harém em aposentos adjacentes às câmaras do sultão. Tratava-se de mais uma inovação desaprovada na Corte. Diante disso, Hürrem seria acusada pelo escritor flamengo Ogier Ghiselin de Busbecq, citado no Capítulo 3, de ter enfeitiçado o sultão, e seria vista como detentora de poder sobre as emoções de Sulaymān (PEIRCE, 1993, p. 62).

O casamento escandalizou a Corte Otomana porque havia muito tempo que um sultão não se unia legalmente a uma mulher. Entre o fim do século XIII e a metade do século XV, os sultões otomanos "contrataram casamentos legais com governantes próximos da Europa e da Anatólia". Após a morte de Mehmet II, contudo, os otomanos, "com a sua pretensão de dominar o mundo, julgaram que nenhuma outra dinastia era digna de aliança marital” (BLAKE, 2013, p. 102). Depois disso, o harém imperial contaria apenas com concubinas escravas. O rompimento com a tradição ocorreria justamente com a união oficial selada entre Sulaymān e Hürrem. Selim II, filho do casal e herdeiro do trono em 
1566, também se casou oficialmente em 1571 com Cecilia Venier-Baffo, depois nomeada Nūr Bānū ${ }^{113}$, filha de um casal grecoveneziano de linhagem nobre ${ }^{114}$.

Como a escravização de muçulmanos era proibi$\mathrm{da}$, as concubinas eram provenientes de terras estrangeiras ou de comunidades não muçulmanas em territórios governados por muçulmanos. Esta última situação era, contudo, "tecnicamente ilegal" (PEIRCE, 1993, p. 31). De todo modo, as escravas levadas para o Império Otomano tinham tanto origem russa, italiana, grega ou balcânica (DAVIS, 1986, p. 100). Quando o Império deixou de se expandir durante o século XVIII, o número de cativas de guerra diminuiu. Isso provocou a compra de escravas circassianas ou georgianas que eram sequestradas em sua terra natal, vendidas por seus pais ou postas voluntariamente nas mãos de mercadores de escravos com a intenção de rumar para Istambul. Lembremos que essa heterogeneidade étnica foi ressaltada por William Lempriere em suas visitas aos haréns marroquinos, além de ter sido sublinhada por Jean Chardin.

O processo para se tornar "a favorita" do sultão era minuciosamente regrado. Inicialmente, aquelas que estavam agrupadas na classe mais alta, ou gedikiler, contavam com o suporte de uma mulher mais velha, a kaya kadin, que as instruía e as orientava sobre as suas vestimentas a fim de que fossem apresentadas ao sultão. Se o governante notasse determinada garota e a escolhesse como possível

113 Nūr significa luz em árabe, e Bānū é um título persa para senhora (ROSSI, 1953, p. 434).

114 Sobre a data do casamento, ver Classen, 2009, p. 654; sobre a origem de Nūr Bānū, ver Freely, 2006, p. 148. 
concubina, ela seria designada como gözde, o que significa que ela estaria sendo observada de perto pelo sultão. Depois disso, a garota seria levada para o seu próprio apartamento e seria preparada por um grupo de servas: a guardiã da banheira, a senhora que cuidava das vestimentas e a guardiã do Tesouro (FREELY, 2011, p. 142).

Após a sua primeira noite com o sultão, se a jovem permanecesse sob sua tutela, ela se tornava uma ikbal [afortunada, em turco], ou seja, uma concubina real. Uma ikbal era, portanto, uma concubina a quem o sultão havia se ligado mais do que às outras. É importante assinalar que a palavra odalisca, usada pelos europeus como equivalente a escrava, tem origem no termo turco ódalik e remete a oda [quarto], significando, então, "aquela que pertence ao quarto" (RABINOW; AAGESEN, 2012, p. 191). Não é corrente encontrar em fontes de viagem do início do período moderno o emprego dessa palavra. Tal prática se torna mais evidente ao longo do século XIX ${ }^{115}$. De todo modo, dentre os autores citados neste livro, o francês Louis Deshayes de Courmenin já usava a palavra odalisca - grafada como Odalique - para designar as escravas no palácio otomano.

Acima da ikbal, estava a concubina favorita. O termo usado comumente para designar as mulheres nessa situação era haseki. Caso a concubina favorita tivesse filhos com o sultão, o seu título e status mudavam. Aqui, nota-se uma divergência entre os autores no tocante aos títulos

115 Durante o século XIX e início do século XX, a palavra odalisca passou a se conectar com "várias iconografias da mulher exótica” (PAL-LAPINSKI, 2005, p. xv). 
obtidos pela concubina favorita. Para John Freely, se uma favorita se tornasse mãe do filho mais velho do sultão, ela seria chamada de birinci kadm (2011, p. 142). Já Cynthia Lowenthal explica a existência de duas categorias a partir da haseki: aquela que tivesse uma filha seria chamada de haseki kadin; já a concubina favorita que desse à luz um menino seria conhecida como haseki sultan (1994, p. 234). Leslie Peirce, de outro modo, afirma que pelo fim do século XVII o título haseki não era mais usado oficialmente, sendo substituído pelo "menos elevado" kadin. Desse modo, as concubinas passariam a ser conhecidas como "primeira mulher" ou chefe [baş kadin], "segunda mulher" [ikinci kadin] e assim por diante (PEIRCE, 1993, p. 108).

A maior autoridade do harém real estava reservada à mãe do sultão reinante ou, como era chamada, valide sultan. O seu poder não era exercido somente sobre as outras mulheres residentes no harém real e sobre os eunucos, as suas atividades englobavam, além disso, obras de caridade e a construção de fundações. A sua agenda poderia contar ainda com atividades diplomáticas. O chefe dos eunucos negros atuava como um "primeiro ministro" da sultana valide, propiciando a ligação entre ela e o ambiente externo ao palácio. A superioridade dessas mulheres em relação às outras era notória, afinal, as mães dos sultões eram "mais bem educadas e desfrutavam de maior autonomia do que a maior parte das outras mulheres" (TURHAN, 2003, p. 48). O elemento de maior destaque em relação à sultana valide, entretanto, estava no seu poder político.

A atuação de sultanas valide em assuntos do governo entre os séculos XVI e XVII foi tão intensa, que esse período viria a ser conhecido como "Sultanato das 
mulheres" [kadinlar saltanatı]. Eis aqui um exemplo evidente de como as representações distorcidas sobre a função das mulheres no harém pode perpetuar erros de interpretação historiográficos. A expressão "Sultanato das mulheres" cunhada pelo "popular historiador" turco Ahmet Refik (1881-1937) - expressão esta que é também título da sua obra - não apenas projetou o tema das mulheres politicamente influentes no palácio real entre 1520 e 1683, como também tornou evidente a ótica misógina de seu autor (PEIRCE, 1993, p. 289). Para Robert Dankoff, a análise de Refik inspirou "preconceitos antifemininos" em autores contemporâneos, os quais expressaram a sua "indignação moral" em relação a práticas "aberrantes ou incomuns" do governo otomano deste período (apud ÇELEBI, 1991, p. 39).

A tese expressa na sua obra de quatro volumes é bastante conhecida porque foi amplamente veiculada. Para Refik, os infortúnios que acometeram o Império Otomano deviam-se às "maquinações de bastidores" feitas por "esposas e mães reais" que, ele alegava, haviam exercido "autoridade dos confins do harém”. A consequência - concluiria o autor - é que "a manipulação ilegítima do poder e da riqueza” em benefício dessas próprias mulheres contribuíra para a perda da supremacia política e econômica de tal império depois da chamada "Era Clássica" (JAYYUSI et al., 2008, p. 881). Se Refik criou a expressão sobre o governo das mulheres, ele não foi, contudo, o primeiro a escrever sobre isso. Já no período moderno, podemos encontrar depoimentos de europeus que se mobilizaram sobre o tema do poder feminino no harém otomano. 
Se em relação à Hürrem as opiniões desfavoráveis já eram abundantes em seu próprio tempo, sobre Nūr Bānū, as descrições eram mais positivas. Casada com Selim II e mãe de Murad III, Nūr Bānū era a nora de Hürrem e de Sulaymān. Por ser veneziana de nascimento, ela buscou manter uma política de favorecimento de Veneza dentro do palácio otomano e, por essa razão, ficaria conhecida entre os seus contemporâneos como "sultana veneziana" (DURSTELER, 2009, p. 365). Diante disso, os embaixadores venezianos relataram extensamente a sua influência política - com destaque para o período de governo do seu filho. A participação de Nūr Bānū foi, além disso, decisiva no acordo de paz que encerrou a quarta "Guerra Turco-Veneziana” ou "Guerra do Chipre” em 1573.

Dentre os sultões que governaram depois de Sulaymān, Murad III é tomado como o mais "devotado à sua mãe e dependente de seu conselho" (PEIRCE, 1993, p. 238). O testemunho do embaixador veneziano em Istambul, Paolo Contarini (1529-1585), contribui para endossar essa hipótese. Ele afirmava que Murad baseava "as suas políticas principalmente sobre o conselho de sua mãe", pois lhe parecia que ninguém ofereceria a ele um "conselho tão amoroso e leal como o dela, daí a reverência que ele dedica a ela e a estima que ele tem por suas qualidades incomuns e por [suas] muitas virtudes" (apud PEIRCE, 1993, p. 238). Outro embaixador veneziano, Gian Francesco Morosini (1537-1596), teceria intensos elogios a Nūr Bānū, alegando que se tratava de uma "mulher de extrema bondade, coragem e sabedoria" ([s. d.] apud FREELY 2011, p. 274). 
Um sinal do poder político de Nūr Bānū se refere ao momento da morte de seu marido, em dezembro de 1574. Consciente das perturbações que tal notícia poderia gerar e buscando preservar a continuidade dinástica, Nūr Bānū evitou que a informação se espalhasse, revelando-a apenas ao grão-vizir, Sokollu Mehmet Pasha (1506-1579). Além disso, ela teria conservado o corpo de Selim em uma caixa de gelo até que seu filho, Murad III, voltasse de seu posto em Manisa. Selim II teria morrido de estupor alcoólico quando estava no banho, dentro do harém. Ele foi sucedido por um de seus filhos, Murad III, que teve os quatro irmãos mais jovens assassinados, de modo que ninguém poderia contestar a sua chegada ao trono.

Murad III governou até 1595, ano de sua morte e momento em que já estava doente e acamado (GRUZINSKI, 2012, p. 113). Quem lhe sucedeu foi o seu filho Mehmet III (g. 1595-1603), cuja mãe, Safiye (c. 1550-1605), é mais uma personagem incluída no "Sultanato das mulheres". Concubina de origem albanesa, Safiye era a favorita de Murad III e, em 1583, quando a sua sogra Nūr Bānū morreu, o seu poder aumentou até culminar na conquista da posição de valide, em 1595. Dentre os eventos ocorridos nesse período, merece destaque a troca de correspondências entre Safiye e a rainha Elizabeth I da Inglaterra. Além das cartas, era comum o oferecimento de presentes de ambas as partes. Dentre tais ofertas, estava o órgão musical entregue por Thomas Dallam ao sultão em 1599 - como vimos no Capítulo 1 -, mas que chegara quebrado ao seu destino (RUGGLES, 2011, p. 21). Para Safiye, a rainha enviara uma carruagem. 
Um dos europeus a relatar o funcionamento do palácio otomano, acentuando o poder de Safiye, foi o terceiro embaixador inglês em Istambul, Henry Lello. $\mathrm{O}$ inglês afirmava que Safiye sempre favorecia e "governava totalmente o seu filho, ainda que o Mufti e [os] soldados tenham muito se queixado dela ao rei, [afirmando que ela era] enganosa e que o governava" ([s. d.] apud GOFFMAN, 2002, p. 124). Já o segundo embaixador inglês em Istambul, Edward Barton, possuía boas relações com a sultana Safiye. Por meio dela, Barton teria "firmemente encorajado o sultão Murad III a atuar contra a Espanha" (ÇELIKTEMEL, 2012, p. 27). Quando assumiu a função de embaixador em 1588, Barton aconselhou a rainha Elizabeth a escrever cartas para o então sultão Murad III e para Safiye, além de orientar sobre o envio de presentes para o governante otomano e também para a sultana valide (JONES, 2004, vol. 14, p. 218).

Além de seu interesse em manter contato diplomático com a rainha inglesa, Safiye foi descrita pelo já citado veneziano, Gian Francesco Morosini, como uma personagem empenhada em favorecer os interesses de Veneza. Exemplo da afinidade de Safiye com Veneza estava na própria relação mantida com Gazanfer, o chefe dos eunucos brancos [Kapı Ağası $\left.{ }^{116}\right]$. Ocorre que Gazanfer era um renegado de origem veneziana que havia sido capturado pelas forças otomanas em 1599. Depois disso, Gazanfer serviria no palácio real e conseguiria manter uma inusual proximidade com o sultão. Com Safiye, Gazanfer teceu uma

116 Kapı Ağası significa, literalmente, chefe ou senhor do portão (AHMED; SADEGHI; BONNER, 2011, p. 183). 
ligação que se tornou tão sólida politicamente, que os dois são apontados como "as figuras de maior poder na Corte de Mehmet III" (FETVACI, 2013, p. 46). Sobre isso, basta lembrar que Hadim Hasan Pasha, que havia sido governador do Egito entre 1580 e 1583, além de baxá entre 1597 e 1598, buscou arruinar a carreira de Gazanfer e pediu ao sultão que ele fosse executado. Mehmet negou o pedido e ainda informou Safiye sobre tal plano. O resultado foi a execução de Hadim Hasan em 1598.

Além de Nūr Bānū, Safiye e Hürrem - citada anteriormente -, outro exemplo feminino a compor esse período de "Sultanato das mulheres" foi a grega Mahpeyker, conhecida como Kösem (c. 1590-1651). A sua "longa carreira" no harém começou quando ela se tornou favorita do sultão Ahmed I (g. 1603-1617) e, depois, sultana valide dos filhos Murad IV (g. 1623-1640) e Ibrahim I (g. 1640-1648). O poder de Kösem continuou a ser exercido nos primeiros anos do governo de seu neto Mehmet IV (g. 1648-1687) que possuía apenas cinco anos quando ascendeu ao trono ${ }^{117}$. A sua influência teve fim em 1651, ano em que ela foi assassinada por ordem de Turhan Hadice, mãe de Mehmet IV, que então "tomou o seu lugar de direito como valide sultan” (FREELY, 2010, p. 182).

A influência política de Kösem no harém otomano foi notada em seu tempo por dois embaixadores venezianos em Istambul. Em 1612, Simeone Contarini (1563-1634) afirmava que Kösem era uma mulher "bela e perspicaz e, além disso, de muitos talentos; ela canta de

117 Para autores como Ágoston e Masters, Mehmet IV estava com sete anos quando herdou o trono real (2009, p. 370). 
forma excelente, por isso, ela continua a ser extremamente bem amada pelo rei” (CONTARINI, 1612 apud PEIRCE, 1993, p. 105). Por ser a favorita do sultão, este a queria ao seu lado constantemente. Cristoforo Valier (1565-1618), de outro modo, não mantinha uma opinião tão favorável sobre Kösem. Em 1616, ele declarava que a valide "pode fazer o que deseja com o Rei e possui o seu coração totalmente, e nada nunca é negado a ela" (VALIER, 1616 apud PEIRCE, 1993, p. 105). Por tais razões, Valier a enxergava como a mais poderosa dos "colaboradores íntimos do sultão" (p. 105). Ainda que fosse assim, Ahmed buscou "evitar a aparência de ser dominado por uma mulher", como ocorrera com o seu pai em relação à mãe deste, Safiye. Diante disso, um de seus primeiros atos foi "remover a sua avó, a sultana Safiye, da política, confinando-a ao Velho Palácio, em janeiro de 1604" (ÁGOSTON; MASTERS, 2009, p. 23).

As opiniões desfavoráveis ao poder político de Kösem foram expressas ainda por quem atuava diretamente no governo otomano. É o caso de Kemankeş Kara Mustafa Pasha (1592-1644) que servira como grão-vizir e também como almirante da marinha otomana. Em 1640, quando o Doge ${ }^{118}$ veneziano Alvise Contarini chegou a Istambul, este entregou a Kemankeş Pasha uma série de cartas de congratulações pela ascensão de Ibrahim ao poder, cartas estas endereçadas à Kösem. As cartas, porém, não chegaram ao seu destino, pois, de acordo com Contarini, o oficial otomano parecia zombar delas. $\mathrm{Na}$ visão

118 Doge era o mais alto magistrado de Veneza e contava com um cargo vitalício (SPERLING, 1999, p. 376). 
de Kemankeş Pasha, "as rainhas-mães dos otomanos são escravas do Grão-Senhor como todas as outras; não [são] parceiras ou chefes de governo, como aquelas nos países cristãos" ([s. d.] apud PEIRCE, 1993, p. 247). Para Peirce, esse tipo de postura - feita por quem havia sido anteriormente escravizado - era uma tentativa de "minar a aura da legitimidade dinástica" cultivada pelas mães dos sultões no período pós-Sulaymān (p. 247).

A última figura feminina de notório poder no harém foi a concubina Hatice Turhan (1627-1683). Turhan possuía origem russa e havia sido feita prisioneira pelos tártaros, como acontecera anteriormente com Hürrem (SOMEL, 2003, p 115). Ela usufruía a posição de baş kadin [primeira mulher] do sultão Ibrahim, filho de Kösem. Com o sultão, ela teve Mehmet, que se tornou governante do Império Otomano após a morte de seu pai. Embora Turhan tivesse conquistado a posição de valide sultana, a ascensão de Mehmet IV ao trono bem como as suas atribuições políticas no harém geraram uma série de problemas. Dentre estes, estava certamente a própria figura de sua sogra, Kösem.

Antes de nos concentrarmos no governo de Mehmet IV, é preciso ressaltar os percalços vividos pelo marido de Turhan. Quando jovem, Ibrahim testemunhou aquele que seria "o primeiro regicídio na história otomana", ou seja, o assassinato de seu irmão mais velho, Osman II (g. 1618-1622), em 1622 (ÁGOSTON; MASTERS, 2009, p. 262). Depois dele, o governo de seu outro irmão e sucessor ao trono, Murad IV, revelou-se extremamente sanguinário. Não bastasse isso, Ibrahim veria Murad IV ordenar a execução de mais três irmãos: Bayezid e Sulaymān, em 
1632, e de Kasim, em 1637. Todos esses eventos desestabilizaram amplamente a saúde física e mental de Ibrahim, que acreditava ser o próximo nos planos de execução palaciana. Ibrahim não estava enganado, pois, ainda que os primeiros quatro anos de seu governo tenham se caracterizado por uma administração estável, ele seria destronado e assassinado no palácio em 1648. Era o segundo regicídio no Império Otomano.

Ibrahim I manteve aliança política com o grão-vizir de seu irmão, Kemankeş Kara Mustafa Pasha, já citado. Este sabia que as medidas adotadas por ele ameaçavam a sua posição. Diante disso, Kemankeş Pasha buscou eliminar a presença do favorito de Ibrahim, Silahdar Mustafa Pasha, incitando o sultão a enviá-lo para uma província distante e, depois, por meio de falsas acusações, convencendo Ibrahim a ordenar a sua execução. Este assassinato deteriorou a relação entre Kemankeş e a mãe de Ibrahim, Kösem, uma vez que ela planejava casar uma neta com Silahdar. As tensões entre o grão-vizir e um grupo aparentemente controlado por Kösem cresceram a tal ponto, que o sultão ordenaria a execução de Kemankeş em fevereiro de 1644.

O agravamento da saúde de Ibrahim, além do extensivo tempo recolhido ao harém, despertaram o descontentamento de "todas as facções em Istambul" (ÁGOSTON; MASTERS, 2009, p. 263). O objetivo desses grupos era evidente: o sultão deveria ser removido do poder. $\mathrm{O}$ assassinato de Ibrahim, contudo, não atenuaria as tensões no palácio. A ascensão ao trono de Mehmet IV (1642-1693), filho de Ibrahim, acentuou, de outro modo, as divergências entre Kösem e Turhan Hatice, que se tornava sultana valide a partir desse momento. $\mathrm{O}$ alvo político seria, 
então, o posto de regente do novo sultão que possuía, em 1648 , seis anos de idade.

Inicialmente, a disputa pelo poder político entre a antiga e a corrente sultana valide pendia para a primeira, uma vez que Kösem mantinha uma aliança com o chefe dos janízaros. Contra estes, os eunucos - dentre eles o chefe dos eunucos negros, Sulaymān Agha - e os pajens do palácio, todos partidários de Hatice Turhan, não conseguiam intervir. A facção de Turhan contava ainda com o apoio do novo grão-vizir, Siyavuş Pasha. Diante disso, os aliados de Turhan propagaram a notícia de que Kösem planejava assassinar Mehmet IV e a sua mãe. Uma traição como essa gerou como consequência a sua remoção imediata do palácio. Além de ser excluída dos negócios políticos, Kösem seria estrangulada por ordem do grupo associado à Turhan, em 1651 (BAER, 2008, p. 46).

Afora a rivalidade surgida entre Kösem e Hatice Turhan, e o posterior assassinato da primeira, é preciso lembrar que Turhan cuidava efetivamente dos negócios do império. Prova disso são as inúmeras trocas de cartas com os grão-vizires e a sua busca por conhecer as diferentes matérias submetidas à administração do governante. A esse respeito, Peirce nos fornece um exemplo prático. Em uma reunião imperial, na qual o tema de debate era a dificuldade de uma província do Egito em pagar os seus tributos anuais, Turhan, sentada atrás de uma cortina, orientava o seu filho de apenas oito anos de idade (PEIRCE, 1993, p. 253). O governo de Mehmet IV conseguiu se manter estável até 1683, ano da "Batalha de Viena" e também da morte de Hatice Turhan. Depois da derrota, 
mesmo demitindo o grão-vizir, Merzifonlu Kara Mustafa Pasha, Mehmet IV seria deposto, em $1687^{119}$.

Mesmo diante de toda a atuação política de Hatice Turhan, não foi este o tema notado por um artista francês que viajou para Istambul na segunda metade do século XVII. Guillaume-Joseph Grelot, que encontrou Jean Chardin em sua viagem e com ele partiu para a Pérsia em 1671, escreveu um texto sobre a sua estadia no Império Otomano, concedendo um breve espaço à sultana valide. Sem citar o nome de Turhan, Grelot afirmava que ela era uma das "maiores e mais brilhantes senhoras que já haviam habitado o Serralho" (GRELOT, 1680, p. 281). Tratava-se de um prelúdio para a matéria principal do item em questão, isto é, um elogio à mesquita Yeni Valide Camii, concluída por Turhan em 1665.

Considerando-se as análises teóricas feitas sobre a participação das mulheres na política islâmica, nota-se uma recorrente postura de reprovação. Desde o período medieval, definiam-se "todas as mulheres como uma ameaça à manutenção da ordem política islâmica", como escreveu Nadia El Cheikh (apud BRUBAKER; SMITH, 2004, p. 147). Para ela, até mesmo os historiadores muçulmanos tendem a retratar a influência política feminina de modo negativo, tornando-a sinônimo de decadência. $\mathrm{Na}$ modernidade europeia, um elemento de peso seria adicionado a já ampla discussão sobre a atuação pública das mulheres nos países islâmicos: a teoria sobre o despotismo asiático, ressaltada por Montesquieu (1689-1755).

119 Mehmet IV não havia dado o seu consentimento prévio para a batalha em Viena, ver Faroqhi; McGowan et al., 1994, volume 2, p. 429. 
Atendo-se somente à crítica feita aos islâmicos - e não possivelmente ao próprio governo francês ${ }^{120}-$, Montesquieu estreitou a relação entre despotismo e harém em duas de suas obras: Cartas Persas [Lettres Persanes], de 1721, e O Espírito das Leis [De L'Esprit des Lois], publicada em 1748. Esse vínculo foi explorado em duas camadas de interpretação nesses textos: (i) o conceito de despotismo era localizado nas sociedades asiáticas, e (ii) o déspota era ligado ao espaço fechado do palácio; no caso das sociedades islâmicas, tratava-se do harém. Era no ambiente do harém, portanto, que o governante sofreria uma perniciosa influência das mulheres.

A íntima ligação entre despotismo e as sociedades asiáticas não era uma criação de Montesquieu. Séculos antes, Aristóteles (384-322 a.C.) já afirmara que os povos da Ásia eram mais servis do que os povos da Europa e que, portanto, aqueles suportavam o "poder despótico sem qualquer desconforto" ([s. d.] apud EL DIWANI, 2009, p. 10). Em consequência, os gregos logravam o direito de dominar os bárbaros. Embora se espelhasse em Aristóteles, o uso que Montesquieu fez do termo era distinto daquele empregado pelo autor antigo. A palavra despotēs, em grego, indicava o poder que um senhor exercia sobre os seus escravos, de modo que o governo despótico possuía a sua "esfera de legitimidade" no espaço doméstico. Somente no momento em que um senhor passava a tratar um homem livre como um escravo é que "déspota se tornava um termo de abuso" (SCHAUB, 1995, p. 20). Para Diana Schaub, foi Montesquieu quem abraçou o neologismo

120 Sobre isso, ver Lowe, 1990, p. 115-143. 
"despotismo" e o tornou central em seu pensamento, designando-o como "sistema de governo" (p. 22).

Ainda que a palavra "despotismo" tenha sido consagrada na obra $O$ Espírito das Leis, Montesquieu já havia feito uso dela nas Cartas Persas. Na Carta 99, ao escrever sobre o governo monárquico - presente na maior parte da Europa -, o autor alertava que tais governos eram instáveis e degeneravam "sempre em Despotismo ou em República” (MONTESQUIEU, 1735, tomo 3, p. 2). $\mathrm{Na}$ Carta 125, um dos personagens persas, Rhedi, afirmava que ao chegar à Europa possuía curiosidade em conhecer "a história e a origem das Repúblicas". Logo em segui$\mathrm{da}$, ele alegava que a maior parte dos asiáticos não tinha $\mathrm{o}$ conceito mais tênue dessa forma de governo, visto que a sua imaginação não lhes permitia compreender qualquer outro sistema que não o despotismo.

No Espírito das Leis, Montesquieu desenvolveu amplamente a sua teoria sobre o despotismo asiático, pautando-se em grande medida em autores de viagem ${ }^{121}$. Dentre essas fontes, a mais utilizada pelo autor francês foi a obra de Jean Chardin, examinada no Capítulo 1. Ainda que conheçamos as suas fontes, Montesquieu foi acusado por seu compatriota, o orientalista Abraham Hyacinthe Anquetil-Duperron (1731-1805), de usá-las seletivamente, de modo a proteger os seus argumentos (BOER, 2004, p. 36). Antes de verificarmos as suas observações sobre o despotismo, cabe lembrar que Montesquieu propunha a divisão dos sistemas de governo em três tipos: republicano, monárquico e despótico, com a possibilidade de o

121 Sobre isso, ver Young, 1978, p. 392-405. 
primeiro assumir a forma de democracia ou aristocracia (MONTESQUIEU, 1803, tomo 1, p. 76-77). Em relação ao despotismo, particularmente, o francês afirmava que este era "por assim dizer naturalizado" na Ásia (p. 165).

Para o autor, um governo despótico era formado apenas por paixões. Uma vez que as paixões faziam-se sentir de maneira mais intensa nos países quentes, era nestes lugares que o despotismo ocorria em maior medida. Colocando-se acima de todos os outros homens, o déspota só poderia ser caracterizado como "naturalmente preguiçoso, ignorante, voluptuoso" (MONTESQUIEU, 1803, tomo 1, p. 92). Não sem razão, as paixões que arrebatavam o príncipe - palavra usada por Montesquieu - tinham lugar no serralho. Era no palácio que o déspota estava sujeito "às paixões mais brutais" (p. 93). Se as paixões podem contemplar significados amplos, não há dúvida quanto a uma de suas definições: a lascívia.

Montesquieu não mencionou a palavra harém nestas duas obras, mas o uso que ele fez do termo serralho indica que o autor buscou caracterizar tanto o palácio quanto o espaço mais recôndito dele, ou seja, o harém. Neste lugar, onde havia o estímulo às paixões, os personagens diretamente ligados a tais sentimentos eram os eunucos e as mulheres. No capítulo dedicado às leis relativas ao governo despótico, o autor deixou registrado que os eunucos eram responsáveis por enfraquecerem "o coração e o espírito" dos príncipes quando estes ficavam trancados na prisão. A clausura a que Montesquieu se referia era, seguramente, uma indicação da vida circunscrita ao palácio ${ }^{122}$.

122 Para uma comparação entre a clausura no harém e no convento, ver Thomas, 1978. 
A consequência da interferência dos eunucos na vida do governante acabava por envolver outro personagem nos negócios públicos: o vizir. Imerso cada vez mais nos assuntos do palácio, o déspota abandonaria o Estado nas mãos do vizir, preferindo cuidar de seus "prazeres privados” (CARRITHERS; MOSHER; RAHE, 2001, p. 237). Esta situação levou Montesquieu a descrever o vizir como o próprio déspota. Não sem motivo, o autor francês assinalou que no governo despótico tudo consistia em "conciliar o governo político e civil com o governo doméstico, os oficiais do Estado com os do Serralho" (MONTESQUIEU, 1803, tomo 1, p. 160). Eis a expressão maior do governo despótico: a sua íntima ligação com a natureza devia-se justamente ao incitamento dos impulsos humanos, ou seja, a sua busca pelo "prazer, pela gratificação e pelo domínio" (CARRITHERS; MOSHER; RAHE, 2001, p. 258).

O papel das mulheres dentro do harém era ainda mais efetivo. A sua sexualidade capacitava-as a reduzir os governantes a personagens passivos e a tomar "as rédeas do poder político para si mesmas" (DOUTHWAITE, 1992, p. 93). Rica, um dos persas a viajar para França, escrevia que na Pérsia as pessoas se queixavam do fato de o governo ser dirigido por "duas ou três mulheres". Sobre isso, ele afirmava que na França era muito pior, pois ali "as mulheres, em geral, governam e aproveitam a autoridade não apenas para tomar decisões por atacado, mas até mesmo para aplicá-las no varejo" (MONTESQUIEU, 1735, p. 28-29). Diante disso, as mulheres deveriam ser controladas para que não usurpassem o poder masculino.

Nas Cartas Persas, as opiniões de Usbeq acerca da relação entre a função feminina e a política são, de fato, 
complexas. Embora este personagem preferisse governos moderados aos severos, ele se opunha ao "menor sinal de autonomia" de suas próprias mulheres (DOUTHWAITE, 1992, p. 93-94). Decorre daí que para ele o despotismo persa mantinha a ordem por "forçosamente separar os sexos, institucionalizando a poligamia e punindo severamente contatos sexuais não autorizados” (p. 94). A conservação da monarquia francesa se dava, de outro modo, pela presença da monogamia, assim como pelo incitamento de intrigas e do consumo - a moda, o luxo e os jogos -, revelados na vida da Corte.

No Espírito das Leis, "o forte contraste entre o governo monárquico limitado" e o governo despótico, que desrespeita "todas as restrições constitucionais e habituais”, ficava evidente (BOESCHE, 1996, p. 173). A crítica de Montesquieu ao despotismo levou a crer que o seu espectro assombrava o autor francês. Fato é que até o século XVIII, "a ligação entre corrupção moral e política, de um lado, e corrupção física, de outro, permanecia acidental" (LEW apud FULFORD; KITSON, 1998, p. 266). Foi Montesquieu quem providenciou uma formulação teórica que relacionasse essas formas de corrupção. Não apenas o medo, apontado por ele como o princípio do despotismo, mas todas as outras paixões na Ásia tendiam a continuar sendo essencialmente físicas. O resultado é que tais paixões acabavam por corromper o governo.

No próprio texto de Jean Chardin é possível verificar o ressaltado poder feminino sobre os governantes na Ásia. O argumento evocado era que o harém - entendido mesmo como uma instituição - promovia uma inversão da hierarquia política, isto é, dentro do gineceu, o poder das 
mulheres se sobressaía em relação ao poder masculino. Escrevendo no momento em que o Shāh Abbas II morria, em 1666, e o seu filho Sefi ascendia ao trono - sob o título de Sulayman (g. 1666-1694) -, Chardin retratava este jovem como um político inexperiente, imerso mais nos prazeres corporais do que na disciplina masculina de liderança. Ao abdicar os assuntos do governo à rainha-mãe e às favoritas do harém, Sefi teria solapado as "próprias fundações da prosperidade persa" (AMES; LOVE, 2003, p. 60). À mesma época, o padre francês Gabriel de Chinon (m. 1670) alegava o grau de influência das mulheres persas mesmo fechadas no harém - sobre o governo de suas casas e do próprio Estado (1671, p. 62).

Um século mais tarde, o texto de Montesquieu se tornava referência para todos os autores que se puseram a tratar o despotismo. Como escreveu Frederick Whelan, a maior parte dos teóricos da segunda metade do século XVIII, e depois desse período, "aceitava a tese do despotismo oriental" (WHELAN, 2009, p. 78). Mais do que isso. Depois de Montesquieu, o despotismo se tornou a chave de leitura na interpretação das sociedades asiáticas de um modo geral e da turca de modo particular. Não era apenas o governo que tal conceito elucidava, mas também "os modos, os costumes e o temperamento dos turcos" (ÇIRAKMAN, 2002, p. 132). Em consequência, os autores europeus do século XVIII afirmariam que a praga, considerada uma doença "oriental”, juntamente com "os janízaros do sultão, os eunucos e o harém, tornavam-se o símbolo da decadência 'Oriental'" (TAKEDA, 2011, p. 107).

Diante desse cenário, cabem alguns apontamentos sobre a historiografia acerca do "Sultanato das mulheres" 
e sobre a atuação política destas mulheres. A interferência do foro privado sobre a política asiática ganhou notoriedade com Montesquieu, mas já era tema de reflexão antes dele. Em relação à dinastia otomana particularmente, ao longo dos séculos XVI e XVII os homens com funções de destaque dentro do Estado "demonizaram e rejeitaram o poder político exercido pelas mulheres como uma aberração que prejudicava a aplicação efetiva da soberania do império" (ANDREA, 2007, p. 15). Nesse sentido, se - como afirmou Ruth Barzilai-Lumbroso - "alguns historiadores turcos" partilharam imagens dos europeus sobre a ilegitimidade do poder político das mulheres turcas (2007, p. 105), deve-se acrescentar que tal postura já aparecia, entrementes, nos textos dos próprios autores turcos.

Contra essa postura e contra a tese do historiador Ahmet Refik, Dana Sajdi defende que o "Sultanato das mulheres" não deve ser tomado como "causa e sintoma do declínio" otomano, mas de outro modo, como um "veículo que assegurou a perpetuação do governo" deste império (SAJDI, 2007, p. 21). Mesmo que se discorde da afirmação de Sajdi, o que cabe ressaltar é a complexidade das relações e das decisões políticas dentro do palácio otomano, característica que, seguramente, estava presente em outras Cortes asiáticas ou islâmicas. Os papéis políticos desempenhados por essas mulheres, assim como as disputas por poder travadas no harém, indicam que o palácio islâmico estava longe de se resumir em um "monólito político”, como enfatizou Peirce (1993, p. 252).

Por fim, a defesa da interferência nefasta das mulheres na política islâmica - alegada tanto por europeus quanto por turcos - traduz a errônea imagem de contraposição 
entre homens e mulheres dentro do palácio. Como já se fez notar, as mulheres com alegado poder político no harém otomano se aliaram a nomes masculinos, até mesmo contra outra mulher, como ocorreu com Kösem e Hatice Turhan. Além disso, se Montesquieu encontrava no harém “a expressão universal" dos desejos masculinos sobre as mulheres (KINGSTON, 2009, p. 12), há que se ter em conta a presença disseminada de rapazes no palácio imperial. Lembremos sobre isso que os quartos de tais rapazes se localizavam na área privada do palácio, assim como as habitações femininas.

\subsubsection{Os povens rapazes}

Em um texto no qual buscava esquadrinhar a estrutura do harém islâmico, o filósofo contemporâneo francês Alain Grosrichard sentenciava, a um só tempo, o aspecto feminino do harém e o caráter "completamente impregnado de sexualidade" revelado por esse espaço (1988, p. 164). Ainda que as duas imagens sobre o harém se configurem em tópos recorrente ainda hoje, nem por isso elas fazem referência direta às fontes teóricas sobre este tema. De acordo com as narrativas de viagem lidas nos dois primeiros capítulos, ficou evidente que tais representações não constituíam unanimidade entre os autores e foram, além disso, ignoradas ou contestadas em muitos desses relatos. Neste item, discutirei apenas o primeiro elemento, voltando ao tópico sobre sexualidade no último item deste capítulo. 
Já se fez notar anteriormente um elemento sobressalente nas narrativas de viagem sobre o serralho islâmico: a extensa presença de jovens rapazes no palácio dos governantes. Assim como as moças que se tornavam concubinas, estes rapazes eram levados ao palácio após serem tomados como cativos em guerras ou comprados de um mercador de escravos. Também para os rapazes, a beleza era um marcador de diferença, uma vez que aqueles de "aparência agradável" seriam conduzidos para a Corte do sultão (PENZER, 1952, p. 237-238). Depois de treinados, eles poderiam assumir funções dentro do próprio palácio ou poderiam ser encaminhados para postos políticos ou militares.

Como escreveu Norman Penzer, os meninos destinados à Escola do Palácio otomano tinham origens variadas. Eles eram da Áustria, Hungria, Rússia, Grécia, Itália, Bósnia, Boêmia, ou ainda da Alemanha, Suíça, Geórgia, Circássia, Armênia e da Pérsia (PENZER, 1952, p. 238). É certo também que a grande maioria desses meninos professava a religião cristã, a qual deveria ser abandonada assim que eles fossem viver no palácio. Como já assinalado, esses garotos ocupavam a terceira Corte do palácio, ao lado dos guardas dos eunucos brancos, dos seus preceptores e, até o fim do século XVI, ao lado do próprio sultão (PEIRCE, 1993, p. 11). Em virtude disso, pôde-se ler em Henry de Beauvau - analisado no Capítulo 1 - a informação de que tais jovens cortavam os cabelos e faziam a barba do governante otomano.

A inserção desses jovens garotos no tema do harém se justifica por uma razão: todo o interior do palácio Topkapi, independentemente do gênero de seus ocupantes, 
"projetava as qualidades do harém" no sentido de "santuário proibido e guardado" (LAD apud BOOTH, 2010, p. 154). Ainda que os autores de viagem relacionassem o harém somente aos quartos femininos, eles não deixaram de notar a presença dos rapazes no serralho imperial. Portanto, nesse caso, o significado de harém como espaço feminino se sobrepunha ao entendimento de harém como espaço limitado a certo grupo de pessoas permitidas pelo soberano. Dada a importância desses rapazes no interior do serralho, há que se projetar a forma como ocorria o seu recrutamento, isto é, como tributo a ser pago pelas comunidades cristãs submetidas ao Império Otomano.

Desde pelo menos o final do século XIV, os turcos instituíram o recrutamento de crianças entre "os seus súditos cristãos dos Bálcãs". Estes é que deveriam, supostamente, abastecer o governo otomano com soldados e administradores (ÁGOSTON; MASTERS, 2009, p. 146). A instituição, nomeada devşirme, decretava que "certa cota de jovens garotos deveria ser forçosamente removida de seus lares e ser enviada para as Escolas do Palácio do sultão" (NADALO, 2011, p. 282). Essas crianças compunham, a partir de então, uma "casta privilegiada de kuls, ou servos pertencentes ao sultão” (p. 282). Como escreveu Daniel Goffman, após o governo de Mehmet II, no século $\mathrm{XV}$, a maior parte dos homens de destaque do império incluindo-se quase todos os grão-vizires até o século XVII - eram kuls (GOFFMAN, 2002, p. 65).

Embora a saída compulsória de suas casas e o abandono de sua cultura fossem tomados como sinal de "derrota e de vergonha", havia compensações, como nomeou Goffman. Na pior das hipóteses, afirma o autor, estas 
crianças poderiam alçar a função de "soldados de infantaria nas celebradas legiões otomanas" (GOFFMAN, 2002, p. 68). No melhor dos cenários, os jovens garotos poderiam se tornar estadistas, como ocorreu com Sokollu Mehmet Pasha, cristão bósnio que chegara à posição de grão-vizir à época do governo de Selim II, marido de Nūr Bānū, já citada.

Uma segunda razão apontada por Goffman a respeito das vantagens do devşirme é que, diferentemente do que se pode ler nas "historiografias nacionais", os turcos nem sempre insistiam na necessidade de esses meninos se livrarem de suas primogenituras. Aqui, novamente, Sokollu Mehmet Pasha nos serve de exemplo, uma vez que ele mantinha contato com a sua família, prestando, inclusive, assistência financeira aos seus parentes. Em casos como este, o recrutamento desses meninos não apenas providenciava uma ajuda monetária às famílias cristãs - o autor cita exemplos de pais que imploravam para que os funcionários recrutassem os seus filhos -, como também servia para ligar "as províncias cristãs ao Estado islâmico através de um sistema de vínculos pessoais e favores" (GOFFMAN, 2002, p. 68).

Quando se estabeleciam nas funções administrativas, "os servos do sultão desenvolviam redes políticas através de artifícios, clientelismo, recompensas e do matrimônio" (GOFFMAN, 2002, p. 68). Ao final do século XVI, haviam se formado facções políticas que, não raro, incluíam figuras femininas e eunucos imperiais, cujo poder estava na habilidade em transitar pelos cenários público e privado da vida do sultão. A atuação desses homens no palácio otomano se tornava ainda mais decisiva quando se 
verifica que os janízaros, os sipahis [membros da cavalaria] e os principais assessores do sultão na Corte tinham todos a condição de kuls, indicando, portanto, o seu distanciamento original da cultura e da religião dos otomanos (COSER, 1972, p. 578).

Como pudemos ler nos dois primeiros capítulos deste livro, a presença de meninos e jovens homens no palácio real estava relacionada, nas narrativas de viagem, às relações homoeróticas entre estes personagens e os homens que ocupavam funções políticas no Império Otomano. Contudo, pouco destaque era dado nesses relatos ao poder político que esses rapazes - na função de janízaros particularmente - alcançaram. Não sem razão, chegou-se a admitir que nas "rebelióes em que os governantes otomanos eram depostos ou assassinados, os janízaros regularmente desempenhavam uma função crucial" (INALCIK; QUATAERT, vol. 2, 1994, p. 415). Como exemplo, há o caso do sultão Osman II (governava desde 1618) cuja deposição e assassinato, em 1622, ocorreram após uma revolta provocada pelos janízaros.

O último personagem a compor o cenário do harém é mencionado nos relatos de viagem com a mesma ou até maior frequência do que as mulheres: trata-se do eunuco. Se a sua presença estava intimamente relacionada a esse espaço do palácio é porque os eunucos desempenhavam funções vitais junto às mulheres, fosse guardando os portões, mantendo a sua segurança, servindo como ligação entre o ambiente interno e externo ou atuando como "intermediários entre o senhor e as suas esposas e concubinas" (EL HAMEL, 2013, p. 198). É sobre os eunucos que versará o último item dedicado aos personagens do harém. 


\subsubsection{Eunucos}

Em todas as descrições sobre o harém imperial feitas em livros de viagem, é possível encontrar menção a este grupo de homens mutilados. A castração tem sido empregada na história como "instrumento de opressão, escravidão, purificação e observância religiosa” (TRACY, 2013, p. 4). Em termos médicos, ela pode ocorrer de três maneiras: pela remoção ou inativação do pênis; pela remoção ou inativação dos testículos; pela remoção ou inativação de toda a genitália masculina. Além das evidentes perturbações físicas e emocionais, um dos nocivos resultados dessa prática era o deslocamento do homem de sua "esfera masculina" e a criação, portanto, de uma fronteira fluida entre masculinidade e feminilidade. Lembremos que os autores de viagem os caracterizavam, de forma recorrente e pejorativamente, como seres efeminados. Sobre isso, o veneziano Ottaviano Bon afirmava que os eunucos recebiam nomes de flores como jacinto, narciso, rosa ou cravo (1608 apud BAROZZI; BERCHET, 1871, p. 90). A mesma asserção era feita por Louis Deshayes de Courmenin na segunda edição da sua narrativa de viagem (1629, p. 164).

$\mathrm{Na}$ sociedade islâmica, a presença de eunucos remete à cidade onde nasceu o profeta: Yatrib, depois nomeada Medina [Madīnah]. Ali, os eunucos eram empregados como cuidadores da tumba de Muḥammad. Embora haja divergências quanto ao personagem que teria instituído tal prática - Nūr al-Dīn, governador da Síria e da Palestina entre 1146 e 1174, ou Șalāh al-Dīn, o Saladino dos textos europeus -, o fato é que havia eunucos protegendo o 
santuário do profeta desde ao menos o século XII. Sobre isso, o viajante de Al-Andalus Ibn Jubayr (1145-1217), que visitou Medina em 1184, alegava que os guardiães desse local sagrado eram "eunucos etíopes e eslavos" (MARMON, 1995, p. 33).

O uso de eunucos no palácio otomano ocorria desde pelo menos o reinado de Murad II (g. 1421-1451). A aquisição de escravos para esse propósito se dava através do mesmo sistema usado para recrutar as crianças nas famílias cristãs balcânicas, ou seja, por meio da instituição do devşirme. Além de serem provenientes da Anatólia e dos Bálcãs, os futuros eunucos tinham também origem na Hungria e, na segunda metade do século XVI, no Cáucaso e, sobretudo, na Geórgia. Os eunucos compunham um grupo de escravos de status elevado, afinal, estavam em contato próximo com o governante e desfrutavam de excelente educação, além de terem acesso a luxuosas vestimentas e acomodações (HATHAWAY, 2005, p. 1).

Como o comércio de homens castrados tinha espaço desde a metade do século XIII no Egito Mameluco, havia nesse país monastérios cristãos que se mantinham através de tal prática. O negócio de escravos-eunucos estava concentrado no Egito, e o Cairo se tornou um local de afluxo de eunucos depois que eles prestavam os seus serviços em Istambul. Tratava-se de um exílio e não de uma escolha dos eunucos, por suposto. Huarțūm, no atual Sudão, era outro centro para onde os escravos eram levados a fim de serem castrados por "barbeiros, monges e médicos" (FAVAZZA, 2011, p. 162). Como a castração era contrária à lei islâmica, o procedimento ocorria nas periferias do império, sendo realizado tipicamente por médicos 
cristãos. Há registros, contudo, de castração dentro do próprio palácio Topkapi, como afirma Hathaway (2005). Para Penzer, os pontos de parada usados pelos exportadores de escravos eram outro lugar possível onde ocorria a castração dos meninos (1936 apud WILSON; ROEHRBORN, 1999, [s. p.]). A criança era colocada em uma cadeira e tinha o pênis e o escroto amarrados com uma corda. Ambos eram removidos o mais rente possível ao corpo por meio de um único golpe de navalha. Depois disso, o "sangramento era interrompido com óleo fervente" e a ferida era envolvida com "extrato de cera e sebo". O estancamento da hemorragia poderia se dar ainda através de areia quente ou de extrato de acácia (WILSON; ROEHRBORN, 1999, [s. p.]).

Para os que sobrevivessem, doenças como infecção do trato urinário e incontinência urinária eram comuns. Como a taxa de mortalidade era alta, esses meninos eram vendidos por um elevado preço tanto para o Império Otomano quanto para a Pérsia. $\mathrm{Na}$ sua chegada ao palácio imperial, os eunucos seriam examinados por um médico que tinha por objetivo verificar se o pênis e os testículos haviam sido totalmente removidos (DAVIS, 1970, p. 190). Essa informação, entretanto, não é um consenso. Jane Hathaway defende que a castração radical ocorria com os eunucos provenientes da África e não com aqueles oriundos da Europa e do Cáucaso, nos quais ocorria a remoção dos testículos e não do pênis (HATHAWAY, 2005, p. 19). Depois disso, eles recebiam uma "sólida educação islâmica”, similar àquela dispensada aos pajens (p. 30). O local destinado a tais aulas era a chamada Escola do Palácio, na terceira Corte, como assinalado anteriormente. Ali, 
esses meninos eram supervisionados por eunucos mais velhos que controlavam, possivelmente, a própria sexualidade desses eunucos, assim como faziam em relação às mulheres.

Uma vez estabelecidos na Corte, os eunucos estariam inseridos na categoria mais baixa dos serviços prestados ao sultão. O treinamento básico se completava quando o jovem eunuco estava com cerca de onze anos. Nesse momento, ele passava a prestar serviços para a mãe do sultão e era inspecionado pelo próprio chefe dos eunucos do harém. A carreira no palácio contava com uma estrutura hierárquica que compreendia o grau de novato [acem], membro da guarda [nöbet kalfası], grau médio [ortanci] e a mais alta posição [hasılli]. O chefe da guarda dos eunucos era escolhido dentro deste último grupo. Como alegava o veneziano Ottaviano Bon, o pagamento dos eunucos era maior do que o dos outros funcionários do palácio (1653, p. 101).

O número de eunucos servindo o sultão otomano aumentou significativamente com o passar dos anos. À época de Selim I, no começo do século XVI, eram quarenta eunucos no palácio. No reinado de Sulaymān, o Magnífico, no mesmo século, a cifra saltou para seiscentos a oitocentos eunucos. O número atingiu o seu pico ao final deste século, sob o governo de Murad III, com mil eunucos compondo a população do palácio Topkapi. Os eunucos eram formados por homens brancos e negros, uma vez que cada grupo desempenhava funções específicas no palácio. De acordo com Jateen Lad, Murad III foi o primeiro sultão a apontar, em 1574, um eunuco de origem etíope - Mehmed Agha - ao posto de chefe dos eunucos negros do harém (LAD apud BOOTH, 2010, p. 142). 
Enquanto os eunucos negros guardavam as mulheres que viviam no harém, os príncipes, os pajens da Corte e os estudantes da Escola do Palácio eram vigiados pelos eunucos brancos. O chefe dos eunucos negros tinha o título de Kızlar A $\breve{g} a s \imath^{123}$, que pode ser traduzido como senhor ou mestre das meninas; já o chefe dos eunucos brancos recebia o nome de Kapı Ăgası, ou senhor do portão. A posição estratégica assumida pelo chefe dos eunucos negros, após o reinado de Sulaymān, deveu-se ao crescimento no número de mulheres no palácio. Além do contato com o pátio em que ficavam os aposentos femininos, este eunuco desfrutava de acesso direto ao sultão - entregando-lhe, inclusive, comunicações advindas do grão-vizir - e de aproximação com a sultana valide, uma "companheira de conspiração" (DAVIS, 1986, p. 21). A localização mesma do apartamento do chefe dos eunucos negros é digna de nota: ficava na entrada do harém. Desse modo, qualquer um que circulasse pelo harém poderia ser observado por ele. Como definiu Emine Fetvaci, este eunuco era o "portão de entrada [gateway] da família do sultão" (2013, p. 150).

Não deixa de ser curioso que o crescimento da importância do Kızlar A ̆gası tenha se dado em uma época em que o império vivia o seu "declínio", ou seja, entre o início do século XVI e o correr do século XVII. Foi no final do século XVI que o posto de chefe dos eunucos do harém imperial passou a ser ocupado por homens negros (HATHAWAY, 1997, p. 139). Lembremos que os episódios conhecidos como "Cerco de Viena" e "Batalha de Viena"

123 Esse chefe era também chamado de Darüssaade Ăgası, guardião do portão da felicidade (HARPER, 2011, p. 46). 
ocorreram justamente nestes séculos: em 1529 e em 1683, respectivamente. Esses eventos vinham se somar a revoltas de grupos nômades - descendentes de turcos e curdos, os Jelali - e a rebeliões de janízaros. Este período se revelava aos otomanos como um momento-chave de necessária adaptação a "novas pressões e a novas realidades, internas e externas" (KAPUCU; PALABIYIK, 2008, p. 68). A função do chefe dos eunucos negros é entendida, portanto, como uma adequação da Corte a este cenário de crise.

Já que os eunucos negros mantinham frequente contato com as mulheres do sultão, os viajantes acreditavam que eles eram selecionados a partir de um traço fundamental: a feiura. Sobre isso, o viajante inglês Paul Rycaut afirmava que os eunucos negros eram escolhidos entre aqueles que apresentavam as "piores características" na "raça Africana” (RYCAUT, 1682, p. 67). No século XVIII, o já citado médico escocês Patrick Russell - residente em Alepo por dezoito anos - afirmava que todos os eunucos nessa cidade eram negros e, ainda que o número fosse insignificante, eles eram "na maior parte notavelmente feios". Somava-se a isso a sua inclinação ao vício da embriaguez e a sua afeição imoderada às mulheres (RUSSELL, 1794, vol. 1, p. 220).

A sexualidade dos eunucos era um tema controverso nos relatos de viagem. Se havia, por um lado, afirmações como a de Patrick Russell que assegurava o interesse físico dos eunucos pelas mulheres, havia viajante que indicava, de outro modo, a ausência de virilidade dos eunucos, como fez o religioso francês Joseph de La Porte (1714-1779) em texto de 1757 (p. 149). Deve-se, contudo, repensar a 
suposta assexualidade desses homens. Como escreveu Shaun Tougher, o casamento era, de fato, uma possibilidade para os eunucos $(2008$, p. 45). Ainda que essa situação fosse mais evidente para os eunucos da Corte Chinesa, a informação também era mencionada pelos viajantes em relação ao Império Otomano. Paul Rycaut assinalava que entre os turcos havia a "conjunção de um eunuco com uma mulher", o que o levava a questionar se tal união poderia receber o "título honroso" de casamento (RYCAUT, 1682, p. 293).

Ainda sobre esse tema, outro autor teceu uma afirmação inequívoca. O romeno Alexander Gika, que escrevia sob o pseudônimo de Elias Habesci - anagrama da expressão árabe "Sahib-el-Sicia" [que significa "amigo dos desafortunados"] -, viveu em Istambul e publicou o seu relato sobre o Império Otomano no século XVIII (PIPPIDI, 2006, p. 286). No livro, o autor dedicou um capítulo sobre, entre outros tópicos, o casamento dos turcos. Ali, Gika defendia que "mesmo os eunucos podem se casar, e vários deles têm muitas esposas, pois a poligamia é permitida" (HABESCI, 1784, p. 106). A edição em inglês de 1784 recebeu tradução para o francês em 1792, mas no lugar de "eunucos" a versão em francês indicava apenas "os estrangeiros" (p. 119).

A presença dos eunucos nos textos de viagem acentuava a imagem de reclusão feminina, uma vez que atestava a fronteira estabelecida entre elas e os outros personagens do palácio, além da necessidade de constante vigilância de um grupo especialmente treinado sobre tais mulheres. Paul Rycaut é apontado como um dos viajantes responsáveis por instituir em sua narrativa a demarcação do harém 
como um "mundo à parte", cuja sensualidade começaria a compor a tradição representativa dos muçulmanos em textos europeus (BERNSTEIN, 2009, p. 75). De fato, os eunucos negros eram figuras lembradas recorrentemente pelos viajantes, cuja função era estabelecer a fronteira entre o espaço permitido e o espaço proibido do palácio. Contudo, é necessário recordar que a imagem sensual ou sexual sobre o harém não era uma premissa dos textos de viagem, como já se fez notar ao longo deste livro.

Se os eunucos negros usufruíam de uma posição estratégica, definindo quem poderia ou não entrar no espaço do harém, eles, de outro modo, estavam liberados desta fronteira. Em uma arquitetura que tinha por objetivo separar, o "verdadeiro poder estava em preservar aqueles que tinham a liberdade de ver e de se movimentar" por este lugar (LAD apud BOOTH, 2010, p. 166). Em um cenário de construções sólidas, as janelas gradeadas nos aposentos do Kızlar A ğası eram um meio de se verificar todos os movimentos e as interações entre os personagens da família imperial. Do lado oposto ao seu apartamento, localizava-se uma curta passagem, nomeada de Kuşhane Kapısı, que "fornecia a única conexão entre as seções masculinas e as predominantemente femininas da casa" (LAD apud BOOTH, 2010, p. 163).

A presença desses três grupos de personagens - as mulheres, os jovens rapazes e os eunucos - aliada, por suposto, à figura do sultão, contribuíram para a construção de uma representação sexual do harém. Como escreve Madeline Zilfi, as imagens sexuais do harém, evocadas por "ocidentais mal informados ou mal intencionados", não foram criadas $a b$ vacuo, afinal, o gênero e a sexualidade 
eram parte integrante da organização da sociedade otomana (ZILFI apud FAROQHI, 2006, p. 231-232). É preciso, todavia, considerar esse problema a partir de duas perspectivas: aquela que se apresenta como uma teoria geral e aquela que nasce das fontes empíricas. No que diz respeito às fontes usadas aqui, o harém era tomado como uma peça a compor o cenário lúbrico islâmico, dado que tal sexualidade se relacionava, tantas vezes, ao envolvimento erótico entre um homem e o sultão, e não entre uma mulher e o governante.

Ao lado da sexualidade, um último elemento ganhou peso na descrição que se fazia do harém no período moderno: a sua estabilidade. Assim como qualquer outra instituição social, o harém se transformou dentro das sociedades islâmicas. Entretanto, as suas mudanças, ou particularidades, despertavam menor interesse nos viajantes do que seguramente o seu caráter estático. Esta forma de representar o harém estava relacionada, certamente, à própria percepção destes autores sobre o momento histórico vivido pelo Levante. Mas o enaltecimento da imobilidade ia além. É sobre este tema que me deterei no próximo item, antes de retomar, por fim, o debate acerca da associação entre a sexualidade e o harém.

\subsection{Imobílídade}

Uma característica notória do harém descrito pelos viajantes era a sua homogeneidade. Isso significa que as mudanças referentes à construção física do harém, assim como a alteração de seus personagens e as vicissitudes 
temporais desse espaço, não eram assim percebidas pelos autores. No lugar de um sistema composto por variáveis, o que se produzia era, ao contrário, uma mesma imagem, repetida com recorrência. É preciso lembrar que a ideia do imobilismo islâmico, de forma ampla, tornou-se mais presente e acentuada ao longo dos séculos. Em viagem à Síria, em 1660, o jesuíta Joseph Besson afirmava que "na França, há modas no vestuário que têm o seu próprio movimento e mudam com o tempo; aqui, a moda não muda nunca; e o árabe de hoje se veste como no século dos sultões e dos califas" (1862, p. 426).

Montesquieu dilatou essa ideia ao escrever que as leis e os costumes, incluindo o modo de se vestir, "são hoje no Oriente como eram há mil anos" (1777, tomo 2, p. 40-41). A causa de tal imutabilidade - título, inclusive, deste capítulo de seu livro - era uma fraqueza natural associada à "preguiça de espírito" (MONTESQUIEU, 1777, tomo 2, p. 40). O outro ingrediente era, por suposto, o despotismo. Decorre daí que a sociedade "estática e servil", associada a uma "política atrasada e corrupta", encabeçada por governantes arbitrários, formavam um "círculo vicioso' do despotismo Oriental". Isso contribuía para se formar a imagem do Império Otomano como o "homem doente da Europa", e ajudava a explicar, em última instância, o próprio declínio desse império (REYNOLDS, 2013, p. 60).

Tal caráter estático possuía uma ligação ainda mais íntima com o harém. Nesse sentido, conceituar esse espaço em diferentes épocas da modernidade europeia significava reiterar igual afirmação, qual seja, aquela que indicava a sua inacessibilidade e o confinamento de um grupo de mulheres fisicamente bonitas e anônimas. A justificativa para 
a reprodução de tal quadro era evidente: como a maior parte das informações sobre o harém não nascia da observação do europeu dentro do palácio, não era possível que estes autores revelassem as particularidades do harém existentes no momento em que viajavam. Portanto, quanto mais se escrevia sobre o harém, mais se perpetuava uma imagem genérica sobre ele.

O caráter estático do harém era resultado ainda da forma como os autores modernos pensavam o lugar da Ásia no processo histórico. A ausência de mudanças e, portanto, o atraso a que muitos viajantes aludiam, se prestavam a fomentar e a cristalizar uma representação persistente sobre as sociedades islâmicas: se havia alguma grandeza a ser destacada, essa se localizava temporalmente no passado. Aqui é importante ressaltar, contudo, que os viajantes dos séculos XVII e XVIII não exprimiam uma voz em uníssono a ponto de abarcar todas as sociedades asiáticas nem sob o epíteto de Oriente, nem sob a imagem de Oriente atrasado. Como já foi notado, esses autores tendiam a destacar o atraso das regiões islâmicas, mas nem por isso deixavam de se contradizer ou mesmo atenuar o que haviam declarado anteriormente.

O harém, de outro modo, era a própria imagem das sociedades asiáticas, com destaque à sociedade islâmica do Império Otomano. O seu caráter estático servia, portanto, para reforçar o mesmo cenário, com iguais personagens e organizado do mesmo modo. Afora o anonimato das personagens femininas no harém ${ }^{124}$, havia a própria

124 Deve-se lembrar que o único viajante que citou os nomes das mulheres que viviam no harém foi William Lempriere; e, ainda assim, somente daquelas que ocupavam posições de destaque junto ao governante. 
imobilidade dessas mulheres dentro do palácio. O médico inglês William Lempriere chegou a ressaltar a impossibilidade de tais mulheres praticarem exercícios físicos, enquanto o francês Joseph Pitton de Tournefort chamava a atenção para a eventualidade com que as mulheres saíam do harém para um passeio de carruagem. Em ambos os casos, o retrato era o mesmo: a clausura. Não sem razão, o harém seria comparado a uma prisão, como fez Jean Chardin.

O fato de ser inacessível para a maior parte dos que frequentavam o palácio real alimentava a crença no seu caráter estático. Essa premissa era aplicada até mesmo quando os autores descreviam a diversidade étnica das mulheres que habitavam os haréns. Ainda que os viajantes - como fez Lempriere - indicassem as múltiplas origens das mulheres que viviam nos haréns islâmicos, uma única característica interessava particularmente: a beleza de tais mulheres. Essa qualidade física das mulheres era reforçada, por sua vez, por outra barreira colocada entre elas e os homens: o uso do véu. Como escreveu Richard Pococke, acreditava-se que as mulheres turcas eram mais belas do que as cristãs, e isso se explicava pelo fato de esconderem o seu rosto atrás do véu. Se a proposição sobre a beleza era verdadeira para as mulheres que andavam pelas ruas, ela era ainda mais enfática para as mulheres que viviam no harém.

A imobilidade do harém se manifestava, além disso, na própria forma como os autores nomeavam o espaço privado do palácio: o harém. A palavra usada no singular, sempre precedida do artigo definido, não deixava margens para a dúvida: tratava-se do espaço mais protegido do palácio, no qual os estrangeiros não poderiam entrar. 
A evocação de seu significado religioso ou proibitivo vinha apenas realçar o valor de exclusividade exibido pelo harém. O local singular e delimitado deveria, então, ser representado apenas como imutável, persistente temporalmente. Quanto mais avançavam as mudanças na História, mais o harém era retratado como a-histórico.

Fosse por necessidade de manter a imagem do harém congelada - como vimos em relação ao uso de cosméticos na França, no Capítulo 3 -, fosse por consequência de certa tradição do "pensamento europeu", o fato notório é que o movimento não era um elemento relacionado ao harém nos textos de viagem. No século XVIII, as mulheres que viviam no palácio Topkapi poderiam sair de lá e construir "mansões privadas ao longo do Bósforo" (DEWALD, 2004 , vol. 3, 2004, p. 132). Todavia, uma vez que não estivessem no harém, como se poderia evocar a imagem do harém enquanto um espaço que abrigava mulheres? Nesse sentido, os textos sobre as mulheres que viviam no harém as representavam como se elas nunca mudassem, ficassem doentes, gerassem filhos ou morressem. Para que a imagem do harém fosse reconhecida, ela precisava ser imóvel.

A marcação de fronteiras dentro do palácio não significava, contudo, o congelamento do comportamento feminino. As suas vidas iam se desenvolvendo não somente através do contato com pessoas fixadas na estrutura interna da Corte, mas também com personagens externos a ela. Quando lemos nas narrativas dos viajantes a aproximação de uma mulher residente no harém com um homem estrangeiro, verificamos tanto o rompimento da exclusividade amorosa com o soberano quanto a transposição da fronteira a ela imposta. Essa imagem já fora ressaltada por 
Baudier e Chardin, e apareceu também em Lempriere. Nesse último autor, ficamos sabendo como embaixadores, cônsules e mercadores, desejosos de obter algum favor junto ao imperador, presenteavam as "principais senhoras do Harém” (LEMPRIERE, 1800, p. 267).

Lempriere, de certa maneira, posicionou-se contra o caráter hermético do harém, ao retirar as mulheres do fundo anônimo e homogêneo ao qual elas eram recorrentemente submetidas e dar-lhes voz e identidade. O harém descrito por ele estava, desse modo, ligado ao movimento. Isso se explicava não apenas pela sua chegada e a alteração sentida nesse lugar, mas também pelo registro das experiências pessoais vividas pelas mulheres que habitavam os palácios. A composição desse quadro, peça a peça, mostrava a ele o dinamismo que movia aquele espaço. O harém, como parte física e social do palácio dos governantes, transformava-se tanto quanto qualquer outro componente das sociedades islâmicas.

De todo modo, o seu propósito maior não era refutar as ideias desfiguradas sobre o harém que circulavam nas mentes e nas bocas europeias. A edição de 1813 de seu livro vem confirmar essa hipótese. Nessa publicação, não era apenas o "caráter de barbárie e ignorância" do Marrocos que era apontada, mas de todo o continente africano. Contrário a isso, Lempriere ressaltava as "vantagens físicas" - leiam-se geográficas - da África. A sua conclusão era enfática: "nas mãos de uma nação iluminada, [a África] pode ser convertida para fins mais benéficos" (LEMPRIERE, 1813 , p. 2). O tema da expansão colonialista europeia, revestido de um clamor pela força conjunta no lugar dos interesses individuais, ganhava preeminência sobre o assunto 
do harém que, embora em destaque na capa da obra, não havia sido expandido no interior dela.

O livro de William Lempriere, assim como os dos outros viajantes citados aqui, mostravam ao leitor o dinamismo da viagem de um europeu contraposto ao cenário de imobilismo do harém. Enquanto os viajantes podiam circular de um espaço para outro, as mulheres que viviam no harém continuavam presas às paredes do palácio. Ou seja, a fixidez espacial era confundida com a fixidez humana, de modo que a descrição do harém real sempre contava com o retrato dos personagens - sobretudo as mulheres - que ali viviam. Foi isso que fez o clérigo inglês Edmund Chishull (1671-1733), ao afirmar que o harém era uma "palavra turca para mulheres", além de equivaler a apartamentos femininos (1747, p. 184). Nas representações europeias, os muros que cercavam o harém mantinham o seu tempo estático.

\subsection{0 harém e a fronteíra sexual}

O caráter imóvel do harém vinha se somar, por fim, ao elemento que lhe era tomado como permanente: a reclusão. A clausura das mulheres era um tópico fértil nas mãos dos autores europeus, uma vez que propiciava os mais variados julgamentos. $\mathrm{O}$ fato é que a concentração das mulheres dentro do espaço fechado do harém era interpretada como um ingrediente certo da manifestação luxuriosa. A repetição dessa tese em cada autor de viagem lhe dava ainda maior autoridade, e o resultado é que a afirmação caminhava para se tornar uma premissa sobre as mulheres islâmicas. 
Em sua narrativa sobre a viagem à Argélia, T.S. defendia que o fato de as mulheres ficarem reclusas despertava as suas "mentes e seus afetos" para aquilo que estava no exterior, longe delas. Portanto, ele alegava, se as mulheres desfrutassem de liberdade, como ocorria em "outros países", "elas não seriam tão furiosamente debochadas" (1670, [s. p.]). Michel Baudier também enxergava na clausura das mulheres - aliada ao calor do clima e ao mau exemplo de seus maridos - o instrumento de estímulo dos amores femininos. $\mathrm{O}$ isolamento das mulheres que viviam no harém tornou-se tema de interesse inclusive dos editores da publicação inglesa Revista das Senhoras [The Lady's Magazine] que, embora questionassem o posicionamento dos viajantes sobre a clausura feminina, emitiam a opinião de que o "confinamento é o mais poderoso ator sobre as paixões” (THE LADY'S MAGAZINE, 1794, p. 314).

Nessa revista inglesa, podia-se ler que o objetivo do confinamento feminino era a manutenção de sua castidade. Porém, o que se verifica nas observações dos autores europeus era a consequência oposta: a inflamação sexual das mulheres. Nesse caso, e em virtude da negligência sexual do soberano, os viajantes afirmavam que elas se relacionavam sexualmente com outras mulheres; utilizavam, ademais, instrumentos para satisfazer seus desejos; ou, ainda, buscavam se envolver com homens que viviam fora da Corte. Vejamos como essas manifestações apareciam nos relatos.

A homossexualidade feminina, embora menos enfatizada do que as relações entre os homens, era um tema presente na literatura de viagem. Jean Chardin informava aos leitores que as "mulheres Orientais" eram conhecidas 
por sua homossexualidade, como foi indicado no Capítulo 1 desse livro. O espaço propício à manifestação de tais relações era, contudo, nos banhos públicos mais do que nos haréns. O hammām era entendido por esses autores como uma justificativa possível para que as mulheres saíssem de sua clausura em certos momentos. Sobre isso, o francês Nicolas de Nicolay afirmava que "entre as mulheres do Levante" havia uma "grande amizade" que ocorria nos banhos. Esses encontros poderiam levá-las à paixão, como se elas estivessem com homens. Uma vez que se sentiam tomadas de lascívia, elas buscavam satisfazer os seus desejos (NICOLAY, 1577, p. 110).

Voltando ao harém propriamente dito, o já citado comerciante francês Seiscentista Jean-Baptiste Tavernier apontava um recurso supostamente usado pelas mulheres que ali viviam. Aprisionadas no palácio, elas estavam sujeitas aos mais diversos excessos, e, em virtude de tal situação, teria nascido a "fábula" sobre o uso de pepinos. Ainda que Tavernier colocasse em dúvida o emprego do dito legume com fins sexuais, ele fazia coro aos outros viajantes mencionados aqui: o "vício" da sodomia assolava Istambul e todas as outras províncias do império, sendo imitado também pelas mulheres (TAVERNIER, 1679, p. 548-549). Afirmações da mesma natureza podem ser lidas em Ottaviano Bon. No seu relato traduzido para o inglês em 1653, o veneziano notava a luxúria das mulheres no serralho e indicava a necessidade de preveni-las da lascívia. Entre as práticas correntes, estava o uso de alimentos como rabanetes, pepinos ou frutos similares que eram empregados em "atos bestiais" (BON, 1653, p. 55). 
O professor de Astronomia na Universidade de Oxford John Greaves (1602-1652), que editou o livro do veneziano Ottaviano Bon em 1653, também tinha o seu parecer sobre o harém imperial otomano. Em 1637, Greaves embarcou para Istambul, partindo no ano seguinte em direção a Alexandria, onde tinha por objetivo fixar a latitude do local em que Ptolomeu fizera as suas observações (HAMILTON; VAN DEN BOOGERT; WESTERWEEL, 2005, p. 85). No item intitulado "Prevenção da luxúria", Greaves alegava que era proibido que se levasse para as mulheres no harém "qualquer coisa" que as permitisse cometer atos de "impureza bestial e antinatural". Portanto, caso essas mulheres quisessem comer rabanetes ou pepinos, por exemplo, estes thes eram entregues devidamente fatiados (GREAVES, 1737, vol. 2, p. 652). O fato de as mulheres serem "todas jovens, vigorosas e lascivas" contribuía para alimentar os seus "pensamentos impuros".

As referências ao uso de legumes com marcadas intenções sexuais extrapolavam os limites do Império Otomano. Lembremos uma vez mais a figura de Niccolò Manucci, que prestou serviços para a Corte Mogol na Índia. O veneziano registrava o episódio nos mesmos termos adotados por John Greaves. Ao explicar que os eunucos proibiam o contato das mulheres com produtos como vinho, ópio, noz moscada ou "outras drogas que poderiam intoxicar”, Manucci ressaltava que eles também não permitiam a entrada de "rabanetes, pepinos ou vegetais similares” (MANUCCI, 1907, vol. 2, p. 351).

A história sobre os legumes usados pelas mulheres no harém endossa o acervo de temas recorrentemente lembrados, mas cuja origem é nebulosa. Dentre aqueles 
grafados pelos viajantes, ele vem se somar ao episódio do lenço jogado aos pés da escolhida do sultão, e à história dos chinelos femininos desconhecidos colocados na porta de determinado aposento no harém, indicando que a dona do quarto recebia uma visita. Tal episódio era evocado pelos autores para denunciar o comportamento lascivo das mulheres, já que os chinelos femininos não passariam de um engodo. Ou seja, uma vez que o senhor do harém estivesse longe de casa, as mulheres poderiam levar um homem para o seu quarto, utilizando-se do artifício dos chinelos, já que elas não seriam incomodadas até que os chinelos fossem removidos dali (LEMPRIERE, 1800, p. 279).

Dentre os artifícios usados pelas mulheres, os viajantes assinalavam, por fim, os encontros com homens que viviam fora do palácio. Para tanto, os homens empregavam um recurso lembrado no "Livro das Mil e Uma Noites", isto é, disfarçavam-se com roupas femininas a fim de se encontrar com as mulheres fechadas no palácio ${ }^{125}$. Tournefort relatava que os homens travestidos em roupas femininas conseguiam se aproximar das mulheres com a justificativa de que eram vendedores de roupas e de joias. O veneziano Manucci também indicava este perigo iminente que rondava a Corte Mogol. Em decorrência disso, os eunucos revistavam todas as mulheres que entravam no palácio com a suspeita de que um jovem homem pudesse estar vestido com roupas femininas (MANUCCI, 1907, vol. 2, p. 351).

125 Sobre esse episódio no texto ficcional, ver "Livro das Mil e Uma Noites". Volume 1 - ramo sírio. Introdução, notas, apêndice e tradução do árabe de Mamede Mustafa Jarouche, (ANÔNIMO, 2005, p. 42). 
Michel Baudier iria mais longe ao assegurar que as mulheres que viviam no harém otomano se relacionavam com estrangeiros cristãos, como os próprios franceses. Mas esses casos amorosos poderiam ter um desfecho trágico, pois as mulheres se livravam deles por meio do punhal ou de uma poção de veneno (BAUDIER, 1631, p. 158). $\mathrm{O}$ autor não esclarecia de que modo elas conheciam os seus possíveis amantes e mantinham encontros com eles. De qualquer maneira, a crença de que as mulheres residentes no harém nutriam relações com outros homens - que não o seu senhor - era um tópico presente na literatura de viagem europeia.

O efeito colateral de tais casos amorosos era óbvio: a exclusividade sexual do senhor do harém era infringida. Embora os viajantes citassem esses supostos casos, eles não questionavam a transgressão da política sexual palaciana. Some-se a isso um desinteresse notório dos autores por aquela que seria a principal relação sexual dentro do palácio: a união entre o soberano e as suas mulheres. A busca por um melhor desempenho sexual era matéria de atenção entre os próprios árabes desde o período clássico ${ }^{126}$. Exemplo de receitas afrodisíacas é o próprio livro escrito pelo polímata persa Nasir al-Din al-Ṭūsī (1201-1274), com edição recente (AL-ṬŪSĪ, 2013). Tal tema, porém, não mobilizava os viajantes. Diante disso, cabe a pergunta:

\footnotetext{
${ }^{126}$ Sobre a extensa produção de "tratados eróticos" pela sociedade árabe, Fatna Sabbah aponta o período do século IX ao XVI como o mais profícuo a este respeito ([s. d.], p. 46). Para Malek Chebel, tal literatura estava interessada em questões "filosóficas, psicológicas, médicas e mágico-religiosas", além de exibir informações técnicas com o intento de orientar e educar o seu público (2003, tomo I, p. 288-290).
} 
se a potência sexual do soberano sequer era considerada, e se as relações entre ele e as suas mulheres ocupavam um espaço mínimo nas páginas dos relatos de viagem, a que lascívia se referiam os autores quando descreviam as sociedades islâmicas?

A partir de todas as informações registradas nas narrativas de viagem, pode-se afirmar que apenas é possível enunciar as relações luxuriosas entre os muçulmanos se considerarmos os encontros entre todos os personagens que viviam na Corte. Em outras palavras, as ligações entre as mulheres e o governante devem ser somadas àquelas entre os jovens rapazes e o imperador, assim como entre as próprias mulheres. De acordo com certos viajantes-autores, haveria ainda a necessidade de se incorporar a esse quadro os personagens externos ao palácio. De todo modo, um fator se revelou inquestionável: o assunto do harém era somente mais um dentre os tantos outros descritos pelos europeus. 